Article

\title{
Impact of the Hydroponic Cropping System on Growth, Yield, and Nutrition of a Greek Sweet Onion (Allium Cepa L.) Landrace
}

\author{
Christos Mouroutoglou ${ }^{1}\left(\mathbb{D}\right.$, Anastasios Kotsiras ${ }^{1}$, Georgia Ntatsi ${ }^{2}$ (D) and Dimitrios Savvas $^{2, *(D)}$ \\ 1 Laboratory of Vegetable Production, Department of Agriculture, University of Peloponnese, \\ 24100 Kalamata, Greece; x.mouroutoglou@uop.gr (C.M.); a.kotsiras@go.uop.gr (A.K.) \\ 2 Laboratory of Vegetable Production, Department of Crop Science, Agricultural University of Athens, \\ 75 Iera Odos, 11855 Athens, Greece; ntatsi@aua.gr \\ * Correspondence: dsavvas@aua.gr; Tel.: +30-210-5294510
}

check for updates

Citation: Mouroutoglou, C.; Kotsiras, A.; Ntatsi, G.; Savvas, D. Impact of the Hydroponic Cropping System on Growth, Yield, and Nutrition of a Greek Sweet Onion (Allium Cepa L.) Landrace. Horticulturae 2021, 7, 432. https:// doi.org/10.3390/horticulturae7110432

Academic Editors: Xun Li, Xiaohui Hu and Shiwei Song

Received: 3 August 2021

Accepted: 14 October 2021

Published: 22 October 2021

Publisher's Note: MDPI stays neutral with regard to jurisdictional claims in published maps and institutional affiliations.

Copyright: (c) 2021 by the authors. Licensee MDPI, Basel, Switzerland. This article is an open access article distributed under the terms and conditions of the Creative Commons Attribution (CC BY) license (https:// creativecommons.org/licenses/by/ $4.0 /)$.

\begin{abstract}
Nerokremmydo of Zakynthos, a Greek landrace of sweet onion producing a large bulb, was experimentally cultivated in a glasshouse using aeroponic, floating, nutrient film technique, and aggregate systems, i.e., AER, FL, NFT, and AG, respectively. The aim of the experiment was to compare the effects of these soilless culture systems (SCSs) on plant characteristics, including fresh and dry weight, bulb geometry, water use efficiency, tissue macronutrient concentrations, and uptake concentrations (UC), i.e., uptake ratios between macronutrients and water, during the main growth, bulbing, and maturation stages, i.e., 31, 62, and 95 days after transplanting. The plants grown in FL and AG yielded 7.87 and $7.57 \mathrm{~kg} \mathrm{~m}^{-2}$, respectively, followed by those grown in AER $\left(6.22 \mathrm{~kg} \mathrm{~m}^{-2}\right)$, while those grown in NFT produced the lowest yield $\left(5.20 \mathrm{~kg} \mathrm{~m}^{-2}\right)$. The volume of nutrient solution (NS) consumed per plant averaged $16.87 \mathrm{~L}$, with NFT plants recording the least consumption. The SCS affected growth rate of new roots and "root mat" density that led to corresponding nutrient uptake differences. In NFT, reduced nutrient uptake was accompanied by reduced water consumption. The SCS and growth stage strongly affected tissue $\mathrm{N}, \mathrm{P}, \mathrm{K}, \mathrm{Ca}, \mathrm{Mg}$, and $\mathrm{S}$ mineral concentrations and the respective UC. The UC of $\mathrm{N}$ and $\mathrm{K}$ followed a decreasing trend, while that of $\mathrm{Mg}$ decreased only until bulbing, and the UC of the remainder of the macronutrients increased slightly during the cropping period. The UC can be used as a sound basis to establish NS recommendations for cultivation of this sweet onion variety in closed SCSs.
\end{abstract}

Keywords: soilless culture; nutrient uptake; sweet onion; nerokremmydo; aeroponic; floating; nutrient film technique; bulb

\section{Introduction}

Onion (Allium Cepa L.) is the second most important vegetable crop after tomato, showing a doubling of production since 2000. The world production (2019) has reached 99.9 Mtons of dry bulbs [1]. Modern paradigms of open-pollinated bulb onion landraces are Kremmydi Thespion [2], Cipolla di Giarratana [3] and Jaune des Cévennes [4] and Nerokremmydo of Zakynthos (meaning "an onion that needs plenty of water"), originating from a Greek Ionian sea island. The latter is a Bermuda type, white-colored, mild, and is marketed in the large to colossal categories [5] from mid-July to November in fresh condition; this landrace achieves two to three times the price of standard varieties. It is sown during the second half of November or in December in low-cost tunnel propagation greenhouses, and is thinned, trimmed, and transplanted up to late March-mid April, yielding $3.5-4.0 \mathrm{Kg} \mathrm{m}^{-2}$.

The limiting area (15-20 ha), labor costs for weed and soil-borne diseases management, such as Allium root rot (Sclerotium cepivorum) and onion pink root (Phoma terrestris) [6,7], are challenges that can be overcome by cultivating in closed soilless culture systems (CSCS). These systems are environmentally friendly, with higher yields and prospect in adverse 
growing conditions areas [8], or where there are soil-borne pathogens [9]. Furthermore, soilless cultivation can be applied to low to moderate cost greenhouses in Mediterranean countries [10], or even indoor plant production in plant factories with artificial lighting [11].

CSCS comprise many techniques in relation to the root environment, such as water culture systems (WCS) including the floating system (FL), nutrient film technique (NFT), and aeroponics (AER), and aggregate systems (AG) [12,13]. AER is a subgroup of WCS, in which, roots grow inside dark, closed containers, and are sprayed at certain intervals with fine droplets of nutrient solution (NS) to maintain a stable aquatic environment that experiences a minimum of fluctuations in ambient nutrient and oxygen levels [14]. Apart from use in research into spaceflight crop production [15], currently AER is used for the production of potato mini-tubers [16], herbs, medicinal root and aromatic plants, and root cuttings $[15,17]$. To maximize outcomes, the technique requires precision sensing technology and a strict dosing regimen [18]. Challenges to overcome include provision of a stable power supply, irrigation components, the position of nebulizers, irrigation program, root available space, and root/NS temperature.

Nutrient and water management is simple, making FL one of the most forgiving and stable CSCS, and concomitantly an increasingly popular option for leafy vegetable production $[9,19]$. In FL, plants are placed in holes on lightweight floating rafts. Roots are totally or partially immersed in the $20-30 \mathrm{~cm}$ NS depth, creating a high volume of NS per plant, with a high buffering capacity [19]. The most important benefits of FL include increasing the useful growing space, and the production of clean and healthy plants. It is considered one of the most suitable WCS for crop propagation and the production of short-lived leafy vegetables such as "baby leaf", "microgreen", and herbs. The system seems to be most useful for single harvest crops [20,21]. Attention should be paid to the aeration, depth, and management of the NS [22].

In NFT, plants are cultivated in pipes or gullies and their roots are permanently surrounded by flowing NS, providing a high ratio of NS surface area to solution volume and the absorption of oxygen from ambient air $[9,20]$. NFT is ideal for short-term crops such as leafy vegetables and herbs, while it is also used for long-term crops, such as cucumbers and tomatoes [23]. Some of the cited advantages [19] include simplified watering, nutrient supply uniformity, rapid turn round of crops, and reduced water and nutrient losses. Cited disadvantages, such as the collapse of crops in the event of power outages, root mass NS impedance in long-term crops, low buffering capacity, and the higher level of management decisions required, should be considered [24].

Aggregate systems are defined as cultivation on porous solid materials other than soil, commonly termed substrates, and are classified into inorganic and organic categories [9]. The composition of solid substrates affects plant physiology, yield and quality [25]. Among the soilless culture systems, the most widely used in South-Eastern European countries for vegetable production, are rockwool, perlite, coir, and pumice. Solid substrates have been used for the production of high-value vegetables, as well as for plant propagation [13]. The biggest challenges in the use of substrates are: ideal selection, i.e., the optimum physicochemical relationship of plant/substrate, purchase costs, available root volume, nutrient management, NS recycling, salinity levels in the root zone, rapid development of nutrient deficiencies, plant/microorganism interactions, reuse, pathogen control, as well as taste and nutritional value $[9,26]$.

A comparison of CSCS, shows fundamental differences in architecture, constituents needed, and sensitivity to failures. When choosing the ideal CSCS, factors such as water and nutrient use efficiency (WUE/NUE), system support, usability, input requirements, production scale, cost and management requirements, and root aeration, should be considered with respect to specific plant species, and their growing and length cycles [19,20,27]. It is also important, when choosing CSCS, that the original systems layout under the same environmental conditions is considered.

An important parameter that differentiates the yield and growth of plants grown in CSCS from that observed in other systems is the morphological and physiological 
properties of the roots that differ significantly depending on the medium in which they are grown [28]. Compared to other WCS, AER plants are reported to have greater root mass [29-31]. Differences observed between WCS and AG are generally significant, in contrast to those observed between different substrates [28].

Nutrient uptake concentrations (ion-to-water uptake ratios) are of great value for the estimation of plant nutrient needs. They exhibit appreciable stability over time under similar climatic conditions and are plant species and developmental stage specific, provided that the root ionic concentrations are relatively stable over the same time period [32-35]. The information available on the composition of NS for onion production is limited [36,37]. It is important to create suitable NS and cultivation protocols for commercial soilless production of fresh bulb onions under Mediterranean conditions. This should include technical adaptations for bulb production, root aeration, NS composition, and irrigation parameters.

In light of this background, the aim of the present study was to compare the agronomic and nutritional response of the Greek onion landrace Nerokremmydo of Zakynthos in four CSCS, aiming to highlight their relative advantages and limitations. Finally, the impact of the CSCS on UCs and nutrient accumulation by onion plants were studied.

\section{Materials and Methods}

\subsection{Systems, Plant Material, Vegetative Growth and Treatments}

The experiment was conducted in an unheated glasshouse constructed with a $1 \%$ slope and an appropriate industrial floor, located at the University of Peloponnese, Kalamata, Greece $\left(37^{\circ} 03^{\prime} \mathrm{N}, 22^{\circ} 03^{\prime} \mathrm{E}, 5 \mathrm{~m}\right.$ a.s.l.). Four of the most widely applied closed soilless culture systems (CSCS), i.e., aeroponic, floating, nutrient film technique, and aggregate (AER, FL, NFT, and AG respectively), were used. A randomized complete block design with 3 replicates per system was used (Figure 1), and each replicate occupied an area of $1.60 \times 1.80 \mathrm{~m}$ (length $\times$ width).

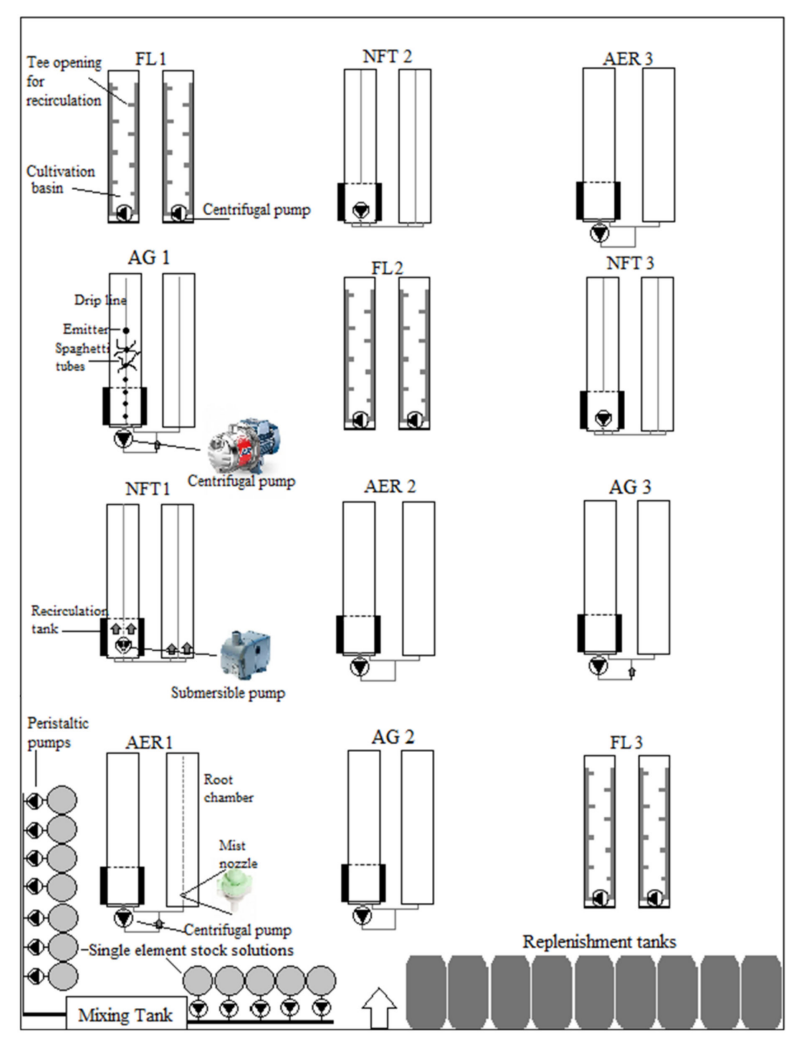

Figure 1. Layout of the 12 experimental units; aeroponic $\left(\mathrm{AER}_{\mathrm{i}}\right)$, floating $\left(\mathrm{FL}_{\mathrm{i}}\right)$, nutrient film technique $\left(\mathrm{NFT}_{\mathrm{i}}\right)$, and aggregate $\left(\mathrm{AG}_{\mathrm{i}}\right) \mathrm{I}=1,2,3$ replicates. 
The root chamber of the AER system was made of extruded polystyrene boards while the NFT and AG systems comprised 4 and 2 PE channels, respectively. The three systems were installed on 2 galvanized bases with a $100 \mathrm{~L} \mathrm{PE}$ tank underneath per replicate used for the recirculation of the $70 \mathrm{~L}$ growth nutrient solution (GNS). Each FL replicate comprised of 2 basins made of Ytong ${ }^{\circledR}$ blocks covered with a $0.5 \mathrm{~mm}$ thick black soft PE sheet containing 390 L GNS each. White Styrofoam ${ }^{\circledR}$ boards, were used for AER, NFT, and FL, being the coverage and/or the floating supporting media for the onion plants. For the AG system, perlite (PerloflorHydro ${ }^{\circledR}$ with a particle size range of $0.5-2.5 \mathrm{~mm}$ ) was used. Information on the irrigation hardware and management is shown in Table 1.

Table 1. Hardware and irrigation management.

\begin{tabular}{|c|c|c|c|c|}
\hline & AER & FL & NFT & AG \\
\hline Pump & $\begin{array}{l}\text { Pedrollo JCR 15H, } \\
\text { Italy }\end{array}$ & $\begin{array}{l}\text { DAB Euroinox } \\
30 / 30 \mathrm{~T} \text {, Italy }\end{array}$ & $\begin{array}{l}\text { Eheim 1001.220, } \\
\text { Germany }\end{array}$ & $\begin{array}{l}\text { Pedrollo JCR 10H, } \\
\text { Italy }\end{array}$ \\
\hline $\begin{array}{l}\text { Application } \\
\text { of GNS }\end{array}$ & $\begin{array}{l}\text { Netafim coolnet } \\
\text { Pro } 65 \text { microns } \\
\text { (4.0 bar })\end{array}$ & $\begin{array}{l}\text { Perforated pipes at } \\
\text { the bottom of the } \\
\text { basin }\end{array}$ & $5 \mathrm{~mm}$ tubes & $8 \mathrm{~L} \mathrm{~h}^{-1}$ \\
\hline Irrigation & $\begin{array}{l}\text { Daily } 1 \mathrm{~min} \\
3 \mathrm{~min}^{-1}\end{array}$ & $\begin{array}{c}\text { System worked } \\
2-3 \text { h day }^{-1} \text { aiming } \\
\text { at } \\
\mathrm{O}_{2} \text { levels between } \\
5-6 \text { ppm }\end{array}$ & $\begin{array}{c}\text { Daily } 0.15 \mathrm{~m}^{3} \mathrm{~h}^{-1} \\
\text { per channel }\end{array}$ & $\begin{array}{l}4-9 \text { irrigation events } \\
\text { day }{ }^{-1} \text { based on solar } \\
\text { radiation integrator, } \\
\text { for a target leaching } \\
\text { fraction of } 0.4\end{array}$ \\
\hline
\end{tabular}

Automatic replenishment of fresh GNS was done by respective $110 \mathrm{~L}$ tanks for AER, NFT, and AG, and directly from the hydroponic head for FL, according to consumption (Figure 1). A threshold value of $3.0 \mathrm{dS} \mathrm{m} \mathrm{m}^{-1}$, for the recycling GNS was chosen for the replacement of GNS. NS pH was recorded daily and adjusted in the range of 5.5-5.7 by adding nitric acid.

Due to a lack of literature on the composition of nutrient solutions for onion bulb production, adaptations were made based on [36-40]. The composition of NS was the same throughout the experiment for all CSCS until harvest. The $\mathrm{pH}, \mathrm{EC}$, macro, and micronutrient concentrations of the tap water and the nutrient solutions used during the experiment are presented at Table 2.

Table 2. $\mathrm{pH}$, electrical conductivity (EC; $\left.\mathrm{dS} \mathrm{m}^{-1}\right)$, macronutrient $(\mathrm{K}, \mathrm{Ca}, \mathrm{Mg}, \mathrm{N}, \mathrm{S}, \mathrm{P} ; \mathrm{mM})$ and micronutrient (Fe, Mn, $\mathrm{Zn}, \mathrm{Cu}, \mathrm{B}, \mathrm{Mo} ; \mu \mathrm{M})$ concentrations in the tap water, in the starter (SNS) and in the growth nutrient solution (GNS).

\begin{tabular}{cccc}
\hline Parameter & Tap Water & SNS & GNS \\
\hline $\mathrm{pH}$ & 7.78 & 5.6 & 5.6 \\
$\mathrm{EC}$ & 0.70 & 2.00 & 2.60 \\
\hline$\left[\mathrm{Ca}^{2+}\right]$ & 2.30 & 3.50 & 4.50 \\
{$\left[\mathrm{~K}^{+}\right]$} & 0.07 & 7.00 & 10.00 \\
{$\left[\mathrm{Mg}^{2+}\right]$} & 1.28 & 1.30 & 1.50 \\
{$\left[\mathrm{Na}^{+}\right]$} & 1.09 & 1.09 & 1.09 \\
{$\left[\mathrm{NH}_{4}{ }^{+}\right]$} & 0.00 & 1.10 & 1.25 \\
{$\left[\mathrm{SO}_{4}{ }^{-}\right]$} & 1.08 & 1.32 & 1.50 \\
{$\left[\mathrm{NO}_{3}{ }^{-}\right]$} & 0.01 & 12.00 & 17.00 \\
{$\left[\mathrm{H}_{2} \mathrm{PO}_{4}{ }^{-}\right]$} & 0.00 & 1.80 & 2.00 \\
{$\left[\mathrm{HCO}_{3}{ }^{-}\right]$} & 4.60 & 0.79 & 1.59 \\
{$\left[\mathrm{Cl}^{-}\right]$} & 1.55 & 1.55 & 1.55 \\
{$\left[\mathrm{Fe}^{2+}\right.$} & 0.00 & 40.00 & 40.00 \\
$\mathrm{Mn}^{2+}$ & 0.00 & 5.00 & 5.00 \\
$\mathrm{Zn}^{2+}$ & 1.07 & 4.00 & 4.00 \\
$\mathrm{Cu}^{2+}$ & 0.00 & 0.80 & 0.80 \\
$\mathrm{~B}$ & 0.00 & 30.00 & 30.00 \\
$\mathrm{Mo}$ & 0.00 & 0.50 & 0.50 \\
\hline
\end{tabular}


Seeds of Greek onion (Allium Cepa) local landrace "Nerokremmydo of Zakynthos", which can be translated as "water onion of Zakynthos", were procured from local producers of Zakynthos Island. On November 26, seeds were sown following standard cultivation procedures and at $140 \mathrm{DAS}$, plants were transplanted, at a density of 13.7 plants $\mathrm{m}^{-2}$. To avoid water evaporation, all experimental units were covered with double-sided PE sheets and all plants were forced to bulb above it. Horizontal net was used for plant support. Plants were kept free from pests following standard greenhouse management practices.

Weekly recordings started 10 days after transplanting (DAT) including the number of green leaves, longest leaf length up to tip and its midpoint diameter (LLMD) [37], pseudostem length, [41] neck diameter, bulb diameter, and height. Based on these measurements, plant height and the bulbing ratio, i.e., maximum bulb: neck diameter (BR), were calculated [41]. Bulb shape characteristics were described with the bulb shape index (ratio of diameter to bulb height) [42,43] and sphericity [44]. During growing, bulb shape firstly adopted a prolate ellipsoid (height $>$ diameter) form and then gradually changed to an oblate ellipsoid (height $<$ diameter) form. Considering this, bulb volume, surface, and sphericity were calculated according to Mohsenin [44] and Stroshine [45].

Onion maturity was rated by visual observation, and was considered to be achieved when $70 \%$ of the tops had fallen over due to softened necks [41,46,47]. Irrigation was then stopped (July 18-233 DAS/95 days after transplant-DAT) and, after cutting off the roots, the bulbs were left to cure, while the remaining leaves gradually dried [46]. The bulbs were harvested 9 days after termination of irrigation (244 DAS/104 DAT).

\subsection{Plant Sampling, Water Use Efficiency, Harvest Indices, Macronutrients and Uptake Concentrations}

Twelve plants (leaves, bulbs and roots) were sampled at 0, 31, 62, and 95 DAT, following growth stages. After weighing, samples were dried at $72{ }^{\circ} \mathrm{C}$ till constant weight in a Raypa DAF 635 (Spain) oven and ground in a Wiley mill (A 11 basic IKA-Germany, Breisgau) to pass a 40-mesh screen. Water use efficiency (WUE) was expressed as the ratio between plant dry weight and the respective NS volume consumed per growth stage. FP, FB, and DP were the fresh plant, bulb, and dry plant weight to total consumed NS (TCNS) [41,48].

The $\%$ plant fresh weight change was calculated based on the plant fresh weight prior to and after curing. Marketable yield $\left(\mathrm{kg} \mathrm{m}^{-2}\right)$ was expressed as the fresh weight of intact bulbs having diameter $>70 \mathrm{~mm}$ per $\mathrm{m}^{2}$. Soluble solids were recorded with a hand-held refractometer, (0-90\% Brix, $0.5 \%$, ATC), harvest index (HI) was calculated as the ratio of the dry weight partitioned to the bulb to the total plant dry mass [47]. The \% of non-marketable bulbs was calculated as the percentage of the number of bulbs with defects, such as decay, split, mechanical damage, and bulbs with a diameter $<70 \mathrm{~mm}$, to the total number of produced bulbs.

Total $\mathrm{N}$ was determined by applying the Kjeldahl method [49]. Phosphorus and $\mathrm{SO}_{4}-\mathrm{S}$ were determined colorimetrically using a Hitachi U2001 spectrophotometer, according to the ammonium molybdate method [50] and turbidimetric method [51], at 460 and $400 \mathrm{~nm}$ respectively. $\mathrm{Ca}, \mathrm{Mg}$, $\mathrm{K}$, were determined by atomic absorption spectrophotometry (GBC $906 \mathrm{~A} / \mathrm{A}$ ) following dry ashing of the plant tissue at $550^{\circ} \mathrm{C}$ and extraction with $\mathrm{HCl}$.

The determination of the macronutrient to water uptake ratios, i.e., apparent uptake concentrations (UC), for $x=\mathrm{N}, \mathrm{P}, \mathrm{K}, \mathrm{Ca}, \mathrm{Mg}$, and $\mathrm{S}$ was based on the amount of $x$ macronutrient recovered from plant tissues and the mean volume of NS per plant that was absorbed by the plants in each circuit of CSCS at the respective growth stage (adapted from Tzerakis et al. [52]), as follows:

$$
\mathrm{UC}_{x}=\frac{\left(C_{x t^{\prime}} \cdot B_{t^{\prime}}\right)-\left(C_{x t} \cdot B_{t}\right)}{V_{u p\left(t^{\prime}-t\right)}}
$$


where $C_{x}, B$, and $V_{u p}$ denote the concentrations $\left(\mathrm{mmol} \mathrm{g}^{-1}\right)$ of the $x$ macronutrient $(x=\mathrm{N}, \mathrm{P}$, $\mathrm{K}, \mathrm{Ca}, \mathrm{Mg} \mathrm{S})$ in plant dry biomass $\left(\mathrm{g}\right.$ plant ${ }^{-1}$ ) and the volume of NS $\left(\mathrm{L} \mathrm{plant}^{-1}\right)$ consumed during the mentioned intervals $\left(t^{\prime}-t=31,62\right.$ and 95 DAT).

\subsection{Statistics}

Statistical analysis was carried out with the Statistica program (StatSoft Inc. Release 12 , Tulsa, OK, USA). Means were compared using Duncan's multiple-range test ( $p \leq 5 \%)$. Data are presented in tables including the statistical significance, and in figures drawn using Microsoft ${ }^{\circledR}$ Excel 13. Figures depict means \pm SE at the 31st, 59th, and 94th DAT, for growth development, and at the 31st, 62nd, and 95th DAT for fresh weight, \% dry matter, mineral concentrations, nutrient solution consumption, water use efficiency, and apparent uptake concentrations of $\mathrm{N}, \mathrm{P}, \mathrm{K}, \mathrm{Ca}, \mathrm{Mg}$, and $\mathrm{S}$.

\section{Results}

\subsection{Conditions}

The climate conditions and root zone temperature during the experiment are presented in Table 3 and Figure 2, respectively. VPD escalated to $1.61 \mathrm{kPa}$ up to 90 DAT. The mean root zone temperature of the water culture systems climaxed above $32{ }^{\circ} \mathrm{C}$ after $76 \mathrm{DAT}$, while mean maximum root temperature of the same systems exceeded $32^{\circ} \mathrm{C}$, after 20 days, with FL presenting the least fluctuation.

Table 3. Mean hourly values ( \pm standard error) of greenhouse air temperature (Tair, ${ }^{\circ} \mathrm{C}$ ), greenhouse air relative humidity (RHair, \%), vapor pressure deficit (VPD-kPa) during experimental period (from 15 April 2014 to 29 July 2014) at time intervals (TI) of 15 days from transplant.

\begin{tabular}{cccc}
\hline TI & Tair & RHair & VPD \\
\hline $1-15$ & $18.70 \pm 0.57$ & $68.36 \pm 1.36$ & $0.84 \pm 0.05$ \\
$16-30$ & $20.81 \pm 0.51$ & $65.13 \pm 1.59$ & $1.06 \pm 0.09$ \\
$31-45$ & $22.44 \pm 0.63$ & $60.64 \pm 1.77$ & $1.31 \pm 0.10$ \\
$46-60$ & $23.59 \pm 0.34$ & $63.99 \pm 1.77$ & $1.22 \pm 0.07$ \\
$61-75$ & $26.17 \pm 0.44$ & $61.90 \pm 2.75$ & $1.54 \pm 0.16$ \\
$76-90$ & $26.77 \pm 0.22$ & $59.86 \pm 1.70$ & $1.61 \pm 0.08$ \\
$91-105$ & $27.18 \pm 0.34$ & $65.65 \pm 1.57$ & $1.42 \pm 0.08$ \\
\hline
\end{tabular}

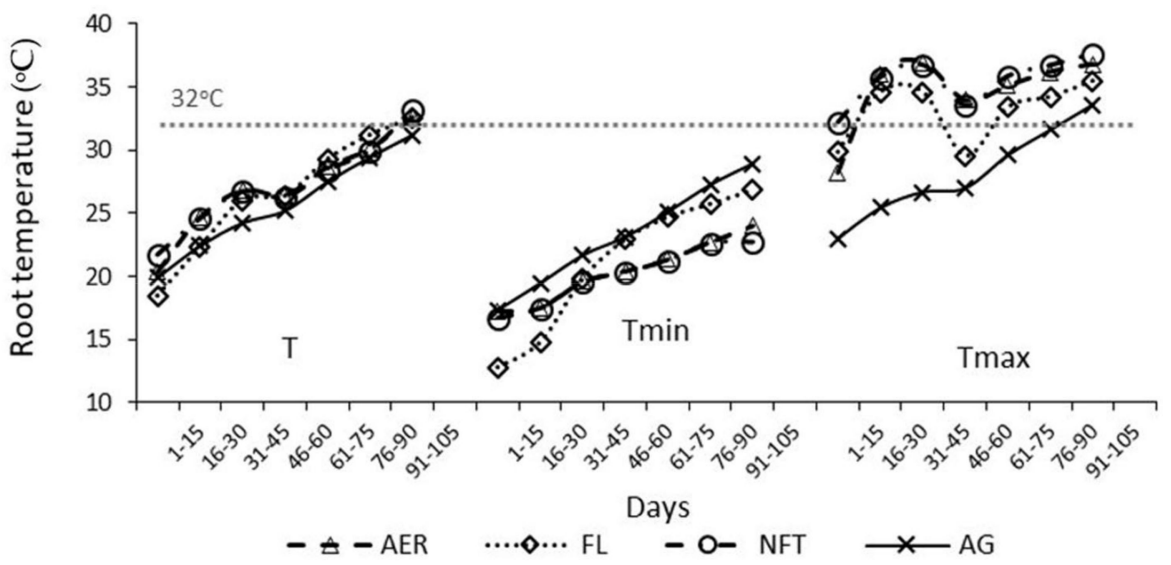

Figure 2. Temperature $\left({ }^{\circ} \mathrm{C}\right)$ in the root zone of the compared CSCS at time intervals (TI) of 15 days from transplant. (I) Mean, (II) Mean minimum, (III) Mean maximum values.

\subsection{Vegetative Development}

At 31 DAT, AG and FL plants were significantly taller, and exhibited longer leaf midpoint diameter (LLMD) than NFT and AER plants, while the neck diameter was significantly higher in AG and FL than in NFT (Figure 3b,c,e). At the same time, NFT recorded the highest pseudostem lengths but the difference was significant only in comparison with 
AER and AG. (Figure 3d). At 59 DAT, FL although not differing from AG plants, exceeded NFT plants in terms of pseudostem length and neck diameter (Figure 3d,e). At 94 DAT, AG and FL plants were significantly taller compared to those in the other CSCS, while the neck diameter was significantly larger than in AER and NFT (Figure 3b,e). Leaf number, pseudostem length, and the LLMD of AG and FL plants were higher than in the rest of the compared systems, with NFT plants presenting the leanest leaf (Figure $3 a, d, c$ respectively). As emerged from the weekly recording (Figure $3 \mathrm{f}$ ), all plants exhibited the maximum values of plant height, LLMD, number of green leaves, and pseudostem diameter at 66 DAT, i.e., $110.75 \mathrm{~cm}, 18.78 \mathrm{~mm}, 13.92$, and $36.81 \mathrm{~mm}$, respectively.

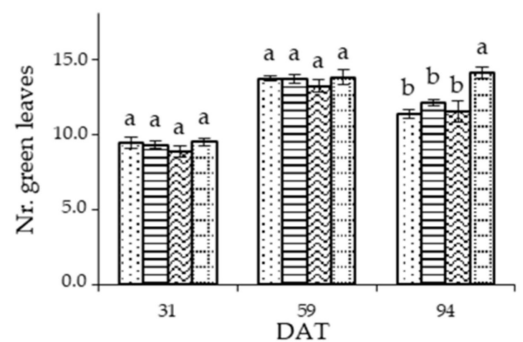

(a)

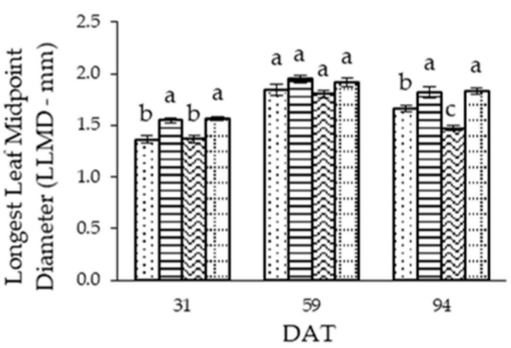

(c)

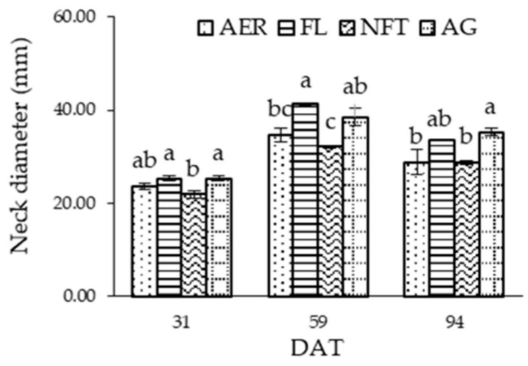

(e)

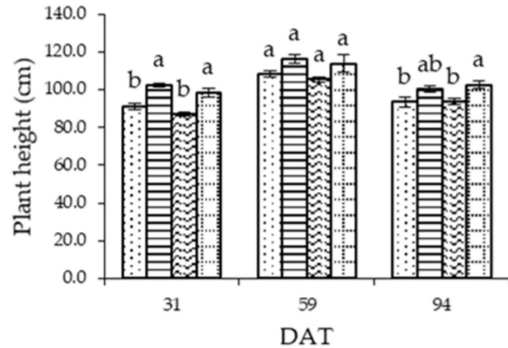

(b)

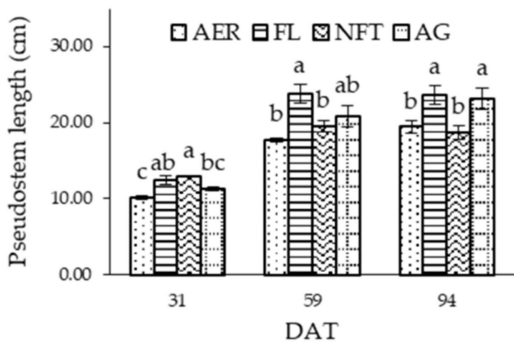

(d)

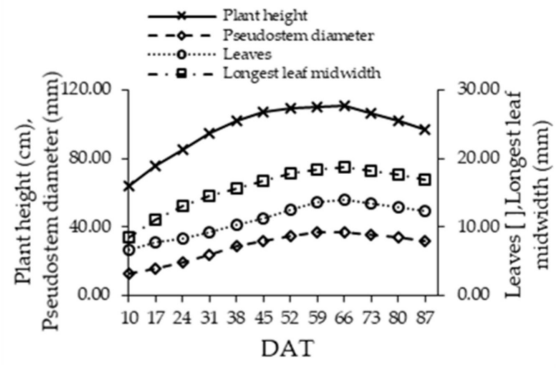

(f)

Figure 3. Impact of the CSCS on vegetative development: (a) number of green leaves; (b) plant height (cm); (c) longest leaf midpoint diameter (LLMD); (d) pseudostem length ( $\mathrm{cm}$ ); (e) neck diameter (mm) at about monthly intervals, i.e., 31, 59, and $94 \mathrm{DAT}$, (f) the average vegetative development of CSCS as indicated by the weekly samplings of plant height $(\mathrm{cm})$, pseudostem width $(\mathrm{mm})$, the number of green leaves, and longest leaf midpoint diameter $(\mathrm{mm})$. Vertical bars indicate \pm standard errors of means of ten (10) measurements per replicate. Similar letters indicate non-significant differences at $p \leq 0.05$.

\subsection{Bulbing and Plant Features during the Bulbing Phase}

According to Figure 4a, 52 DAT, NFT plants showed a significantly higher bulbing ratio and the least shape index in comparison to FL and AG plants. NFT plants entered the bulbing phase $\left(\mathrm{BR}_{\mathrm{NFT}}=2.18>2\right)$ at $59 \mathrm{DAT}$, followed by AER plants $\left(\mathrm{BR}_{\mathrm{AER}}=1.96\right)$. The remainder entered bulbing approximately one week later, i.e., 66 DAT. At that time, bulb 
diameter, number of green leaves, and shape index were not affected (Figure $4 b, c, d$ ). NFT plants showed a higher bulbing ratio than FL and AG plants, while the number of green leaves was significantly lower than that of AG. Additionally, the bulb diameter of FL was greater than in the rest of treatments, while the shape index was not affected (Figure $4 a, c, d$ ). The neck diameter of NFT was steadily smaller than that of FL plants throughout the preand bulbing period (Figure 4e). For the prevailing conditions, the day length to enter bulbing was more than 14:30 h (Figure $4 \mathrm{f}$ ). As presented in Figure 5, at the 62nd DAT, plants showed a different root size, and coloration. AER and FL plants developed the largest, and AG plants the smallest, root system. Based on root color (with white being the most functional and brown being the most aged), the root system of AG appeared to be the healthiest, followed by AER and NFT, while the least healthy root system was observed in FL plants. Finally, there was a notable mass of new roots in FL and NFT plants.

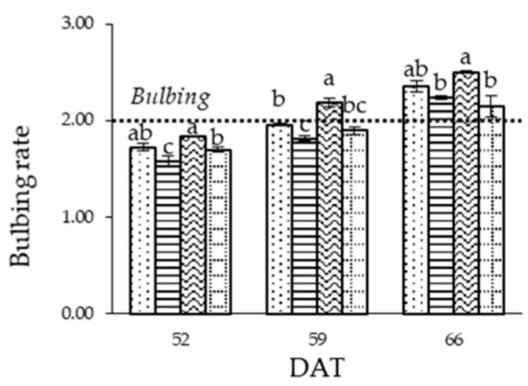

(a)

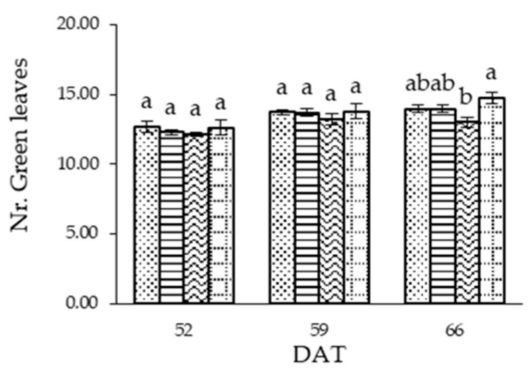

(c)

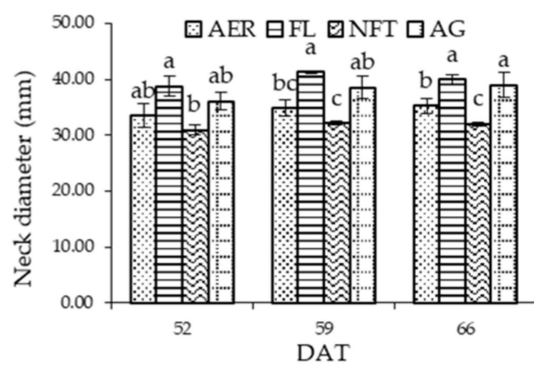

(e)

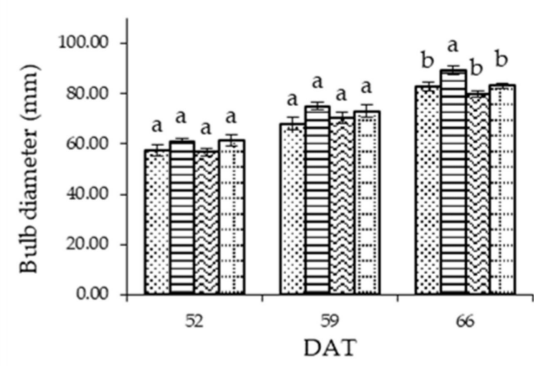

(b)

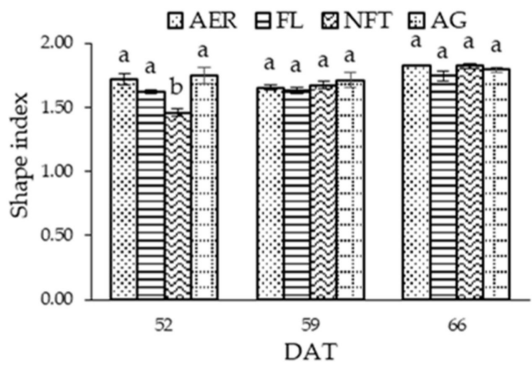

(d)

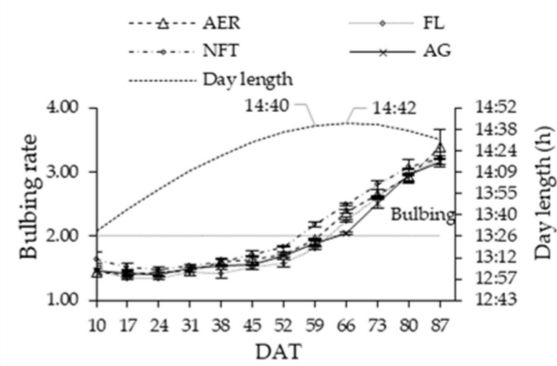

(f)

Figure 4. Impact of the CSCS on: (a) the bulbing rate described as the quotient of the bulb to minimum sheath diameter $\geq 2$; (b) the bulb diameter $(\mathrm{mm})$; (c) number of green leaves; (d) the shape index; (e) the neck diameter at the 52nd, 59th, and 66th DAT; (f) bulbing rate against time; (days) and day length for the trial location. Vertical bars indicate \pm standard errors of means of ten (10) measurements per replicate. Similar letters indicate non-significant differences at $p \leq 0.05$. 


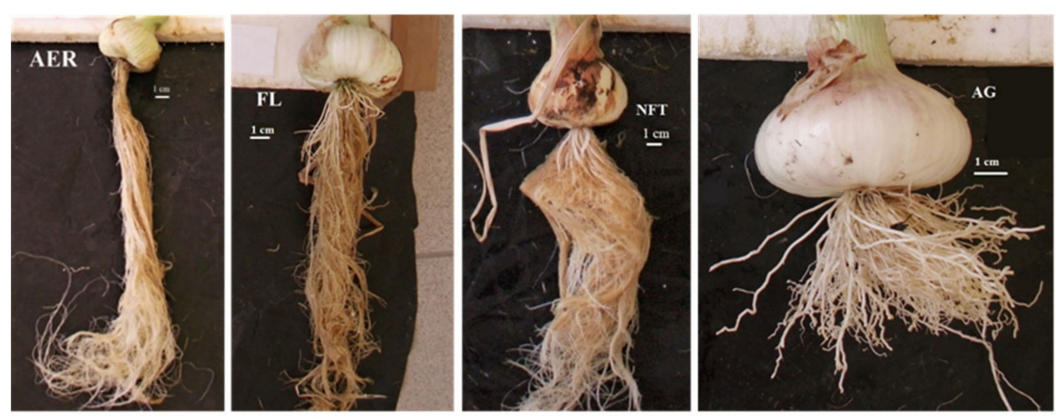

Figure 5. Bulbs and roots of the compared CSCS at 62 DAT (by C.M.).

\subsection{Bulb Characteristics}

The bulb shape index measured at 31 DAT was significantly higher in AG than in AER and NFT plants, in contrast to sphericity, where AER exceeded FL and AG plants (Figure 6e,f). Thereafter, the bulb shape characteristics were not affected. At the same time, no treatment effect were recorded for the remainder of the bulb characteristics. At 59 DAT, FL bulbs recorded the greatest height without any further effects on the bulbs (Figure 6b). At the end of the experiment (94 DAT), FL and AG plants had formed significantly larger bulbs (diameter, height, surface, and volume) compared to those grown in the AER system, while NFT produced the smallest bulbs (Figure 6a-d).

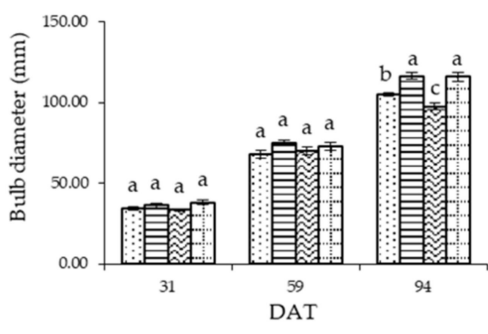

(a)

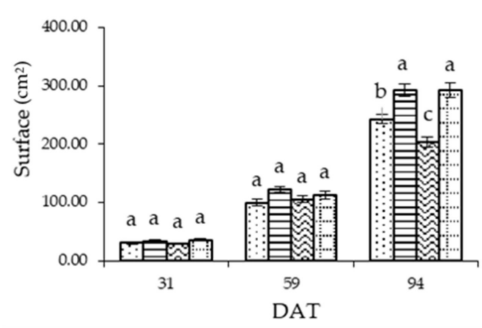

(c)

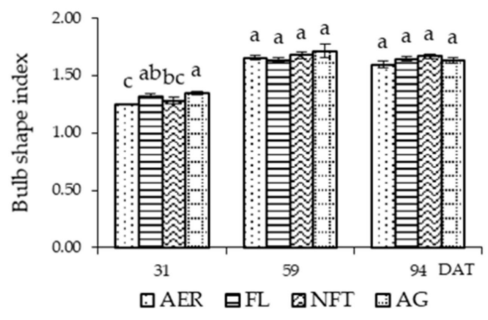

(e)

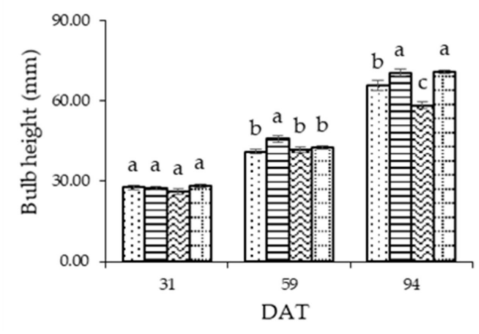

(b)

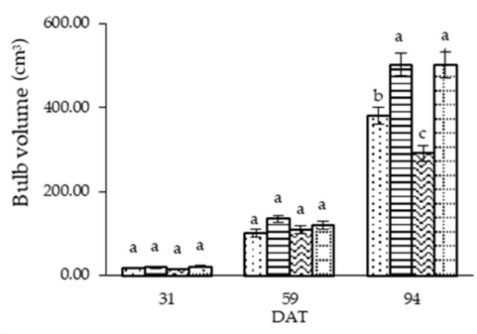

(d)

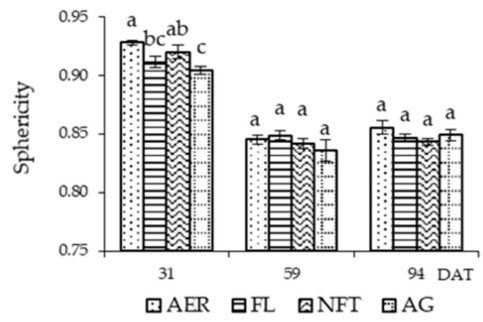

(f)

Figure 6. Impact of the CSCS on bulb characteristics: (a) the diameter (mm); (b) the bulb height (mm); (c) the surface of the bulb $\left(\mathrm{cm}^{2}\right)$; (d) the volume of the bulb $\left(\mathrm{cm}^{3}\right)$; (e) the bulb shape index and (f) the sphericity of the bulb during the 3 samplings (I, II, III), i.e., 31, 59, and 94 DAT. Vertical bars indicate \pm standard errors of means of ten (10) measurements per replicate. Similar letters indicate non-significant differences at $p \leq 0.05$. 


\subsection{Plant Fresh Weight and \% Dry Matter}

The fresh weight of FL plants was significantly higher than that measured for the rest of the treatments at 31 DAT. Thereafter, at 62 and 95 DAT, the highest plant fresh weight was recorded in FL and AG plants, while the plants grown in the NFT system recorded the minimum values. Overall, the \% dry matter of FL plants was significantly lower than that measured in the other CSCS while, at the 3rd sampling date, NFT outperformed AER and FL plants (Table 4).

Table 4. Impact of CSCS on plant (i) fresh weight (FW-g) and (ii) on \% dry matter (\% DM) during the 3 samplings (I, II, III), i.e., 31, 62, and 95 days after transplant.

\begin{tabular}{ccccccc}
\hline Soilless Culture Systems & \multicolumn{3}{c}{ FW (g) } & \multicolumn{3}{c}{ DM (\%) } \\
\hline & (I) & (II) & (III) & (I) & (II) & (III) \\
\hline AER. & $192.76 \mathrm{~b}$ & $475.25 \mathrm{~b}$ & $617.91 \mathrm{~b}$ & $6.04 \mathrm{a}$ & $6.92 \mathrm{a}$ & $8.22 \mathrm{~b}$ \\
FL. & $214.96 \mathrm{a}$ & $598.73 \mathrm{a}$ & $816.04 \mathrm{a}$ & $5.36 \mathrm{~b}$ & $5.98 \mathrm{~b}$ & $7.85 \mathrm{c}$ \\
N.F.T. & $177.19 \mathrm{~b}$ & $343.92 \mathrm{c}$ & $523.04 \mathrm{c}$ & $6,13 \mathrm{a}$ & $6.98 \mathrm{a}$ & $8.73 \mathrm{a}$ \\
AG. & $176.19 \mathrm{~b}$ & $583.75 \mathrm{a}$ & $793.99 \mathrm{a}$ & $6.17 \mathrm{a}$ & $7.06 \mathrm{a}$ & $8.44 \mathrm{ab}$ \\
\hline Statistical Significance & \multirow{2}{*}{ SYSTEM } & $* * *$ & $* * *$ & $*$ & $*$ & $*$
\end{tabular}

Averages ( $n=12)$ where followed by different letters under the same column show statistically significant differences for each factor according to Duncan's multiple range test. ${ }^{*}, * *$, and ${ }^{* * *}$ show significant differences at the level of $p \leq 5 \%, 1 \%$, and $0.1 \%$ respectively.

\subsection{Yield and Quality Features}

The $\%$ plant fresh weight changed during the curing process and the soluble solids were not affected by the CSCS and averaged $24.5 \%$ and 8.22 , respectively (Table 5 ). The marketable yield performance of the four tested CSCS was as follows: FL = AG > AER > NFT. The \% dry matter in bulbs was similar for the AG and NFT plants while it was lower in bulbs produced in AER and FL, but the difference was significant only in comparison with AG. The lowest harvest index was recorded in NFT plants but the difference was significant only in comparison with the AER and FL plants. Finally, the highest \% of nonmarketable bulbs was recorded in the NFT plants, while the AG plants did not produce any non-marketable bulbs.

Table 5. Impact of the CSCS on: (i) the \% plant weight change prior and after curing (PWC-\%); (ii) the yield ( $\mathrm{Y}-\mathrm{kg} \mathrm{m}^{-2}$ ); (iii) the bulb \% dry matter (\% BDM); (iv) the harvest index (HI); (v) the \% non-marketable bulbs (\%) and (vi) the soluble solids (SS-Brix).

\begin{tabular}{ccccccc}
\hline Soilless Culture Systems & PWC (\%) & $\mathbf{Y}\left(\mathbf{k g ~ m}^{-\mathbf{2}}\right)$ & BDM (\%) & HI & NMB (\%) & SS (Brix) \\
\hline AER & $23.53 \mathrm{a}$ & $6.22 \mathrm{~b}$ & $8.03 \mathrm{~b}$ & $0.7018 \mathrm{a}$ & $5.56 \mathrm{~b}$ & $8.13 \mathrm{a}$ \\
FL & $25.17 \mathrm{a}$ & $7.87 \mathrm{a}$ & $7.94 \mathrm{~b}$ & $0.711 \mathrm{a}$ & $5.56 \mathrm{~b}$ & $8.28 \mathrm{a}$ \\
NFT & $24.49 \mathrm{a}$ & $5.20 \mathrm{c}$ & $8.16 \mathrm{ab}$ & $0.678 \mathrm{~b}$ & $16.67 \mathrm{a}$ & $8.12 \mathrm{a}$ \\
AG & $24.80 \mathrm{a}$ & $7.57 \mathrm{a}$ & $8.56 \mathrm{a}$ & $0.706 \mathrm{ab}$ & $0.00 \mathrm{c}$ & $8.36 \mathrm{a}$ \\
\hline Statistical significance & & \multirow{2}{*}{$* * *$} & $*$ & $*$ & $*$ & \multirow{2}{*}{ N.S. } \\
SYSTEM & N.S. & $*$ & & &
\end{tabular}

Averages $(n=12)$ where followed by different letters under the same column show statistically significant differences for each factor according to Duncan's multiple range test. N.S., ${ }^{*}$, and ${ }^{* * *}$ show non-significant differences or significant differences at the level of $p \leq 5 \%$ and $0.1 \%$, respectively.

\subsection{NS Consumption-WUE}

The consumption of nutrient solution (Table 6) was significantly less in NFT at 62 DAT, compared to the other three CSCS, while at crop termination no significant difference was found. The WUE of AG plants was significantly greater during the 2nd sampling, while during the 3rd, FL, NFT, and AG did not differ from each other. At harvest, the fresh plant and bulb WUE of AG and the FL plants presented the highest values, while the WUE of dry weight of AG plants was significantly higher than the remainder, followed by FL, and last NFT and AER, without differing from each other. 
Table 6. Impact of the CSCS on: (A) the consumption of nutrient solution (CNS- $\mathrm{L} \mathrm{plant}^{-1}$ ) and on the total consumption of nutrient solution (TCNS-L plant ${ }^{-1}$ ), B) the water use efficiency (WUE) expressed as the dry weight produced (g) per L of nutrient solution consumed (WUE- $\mathrm{g} \mathrm{L}^{-1}$ ) during the 3 samplings (I, II, III), i.e., 31, 62, and 95 DAT and as the fresh weight of the plant (FP), the bulb (FB) and the dry weight of the plant (DP), $\left(\mathrm{g} \mathrm{L}^{-1}\right)$ at harvest divided by the TCNS.

\begin{tabular}{|c|c|c|c|c|c|c|c|c|c|c|}
\hline \multirow{3}{*}{$\begin{array}{l}\text { Soilless } \\
\text { Culture } \\
\text { Systems }\end{array}$} & \multicolumn{3}{|c|}{ CNS } & \multirow[t]{2}{*}{ TCNS } & \multicolumn{6}{|c|}{ WUE } \\
\hline & (I) & (II) & (III) & & (I) & (II) & (III) & FP & FB & DP \\
\hline & \multicolumn{4}{|c|}{ L plant $^{-1}$} & \multicolumn{6}{|c|}{$\mathrm{g} \mathrm{L}^{-1}$} \\
\hline AER. & $3.57 \mathrm{a}$ & $7.23 \mathrm{a}$ & $6.93 \mathrm{a}$ & $17.73 \mathrm{a}$ & $2.96 \mathrm{a}$ & $2.95 \mathrm{bc}$ & $2.60 \mathrm{~b}$ & $34.09 \mathrm{~b}$ & $25.36 \mathrm{~b}$ & $2.87 \mathrm{c}$ \\
\hline FL. & $3.75 \mathrm{a}$ & $7.23 \mathrm{a}$ & $7.04 \mathrm{a}$ & $18.02 \mathrm{a}$ & $2.80 \mathrm{a}$ & $3.38 \mathrm{~b}$ & $4.03 \mathrm{a}$ & $44.65 \mathrm{a}$ & $31.74 \mathrm{a}$ & $3.57 \mathrm{~b}$ \\
\hline N.F.T. & $3.13 \mathrm{a}$ & $5.58 \mathrm{~b}$ & $6.38 \mathrm{a}$ & $15.09 \mathrm{~b}$ & $3.15 \mathrm{a}$ & $2.36 \mathrm{c}$ & $3.39 \mathrm{ab}$ & $33.74 \mathrm{~b}$ & $24.86 \mathrm{~b}$ & $3.03 c$ \\
\hline AG. & $3.02 \mathrm{a}$ & $7.03 \mathrm{a}$ & $6.6 \mathrm{a}$ & $16.65 \mathrm{a}$ & $3.32 \mathrm{a}$ & $4.33 \mathrm{a}$ & $3.91 \mathrm{a}$ & $46.86 \mathrm{a}$ & $32.95 \mathrm{a}$ & $4.03 \mathrm{a}$ \\
\hline
\end{tabular}

Statistical

significance

SYSTEM

N.S.

*** N.S.

N.S.

**

$* * *$

$* * *$

$* * *$

Averages $(n=12)$ where followed by different letters under the same column show statistically significant differences for each factor according to Duncan's multiple range test. N.S., ${ }^{*}, * *$, and ${ }^{* * *}$ show non-significant differences or significant differences at $p \leq 5 \%, 1 \%$ and $0.1 \%$ respectively.

\subsection{Macronutrients-Uptake Concentrations}

According to Figure $7 \mathrm{a}$, the total-N concentration in the plant tissue recorded a concentration peak at 31 DAT with a decreasing tendency for the rest of the experimental period. Nevertheless, the total-N concentration at the end of the experiment (95 DAT) averaged $39.29 \mathrm{mg} \mathrm{g}^{-1}$, a value larger than the original value of $33.56 \mathrm{mg} \mathrm{g}^{-1}$ before the transplant to the CSCS. The CSCS influenced the tissue concentration of total-N at the 2nd and 3rd sampling of the trial with the AG plants presenting the lowest values (40.56 and 35.14, respectively). The UC were affected during the second sampling (62 DAT) with the NFT plants presenting the lowest value $\left(7.56 \mathrm{mmol} \mathrm{L}^{-1}\right)$ (Figure $7 \mathrm{~b}$ ).

The tissue P concentration showed a slight increasing tendency throughout the trial, which was followed by a commensurate increase in the UC of P (Figure 7c,d). P tissue concentrations were not affected by the CSCS during the first 2 samplings (i.e., 31 and 62 DAT). The AG plants showed significantly less P tissue concentration than the AER and NFT plants at the end of the trial (95 DAT). At the same time, AG and FL plants presented the highest $\mathrm{UC}$ values (1.01 and $0.98 \mathrm{mmol} \mathrm{L}^{-1}$, respectively).

The CSCS affected the tissue concentration of K. After a sharp increase up to 31 DAT, there was a small decline without falling to the initial levels, with an average of $49.46 \mathrm{mg} \mathrm{g}-1$ at the end of the trial. At 31 DAT, AER plants exhibited significantly larger K concentrations compared to NFT and AG plants (Figure 7e). At 62 DAT, the AG plants exhibited the minimum $\mathrm{K}$ tissue concentrations $\left(48.88 \mathrm{mg} \mathrm{g}^{-1}\right)$, while at the end of the experiment, AER plants recorded the highest value compared to all other treatments $\left(53.37 \mathrm{mg} \mathrm{g}^{-1}\right.$ ). There was a similar decline of the K UC following the decline of the tissue K concentration that averaged $4.26 \mathrm{mmol} \mathrm{L}^{-1}$ (Figure 7f). The K UC of the compared CSCS plants showed significant differences during the two last sampling dates. The AG along with the FL plants exceeded AER and NFT plants during the 2nd sampling (i.e., 62 DAT), while the AER plants exhibited the lowest UC at the last sampling date (95 DAT).

The tissue Ca concentrations showed an increasing trend, (Figure 8a) with the AG and FL plants exhibiting a smoother increase and NFT plants recording a decline at the end of the experiment. AER plants recorded the highest value at the 1st and the last sampling dates, without any significant difference compared to NFT plants, which exhibited the highest value during the 2 nd sampling, without any significant difference compared to the AER plants. The Ca UCs of AER, FL, and NFT showed a slight increasing pattern during the cropping period, while AG plants seemed to stabilize the Ca UC after 62 DAT (Figure $8 \mathrm{~b}$ ). The Ca UC were influenced by the CSCS only during the 1st period of growing (main growth period); the NFT and AER plants exhibited significantly higher UC values than FL plants. 


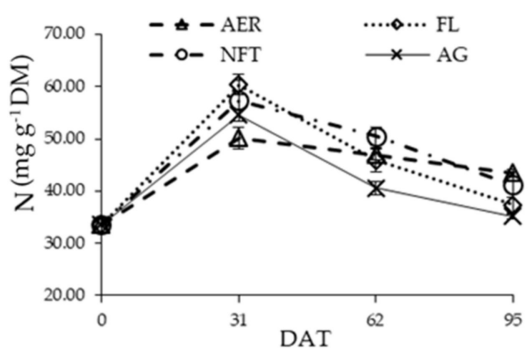

(a)

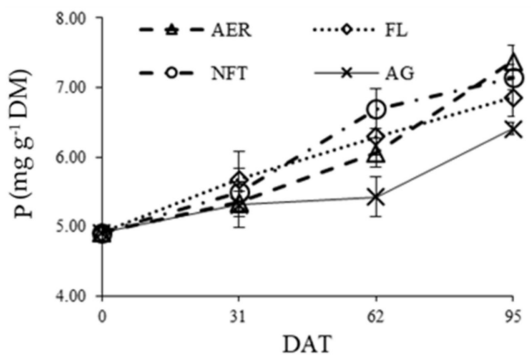

(c)

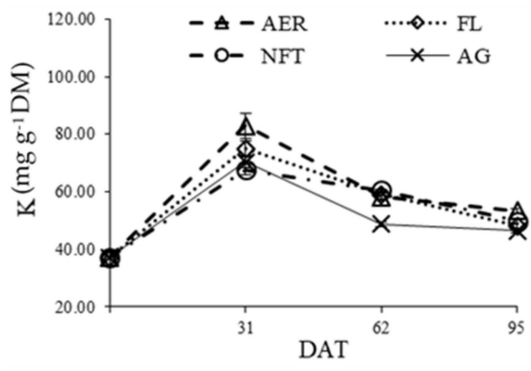

(e)

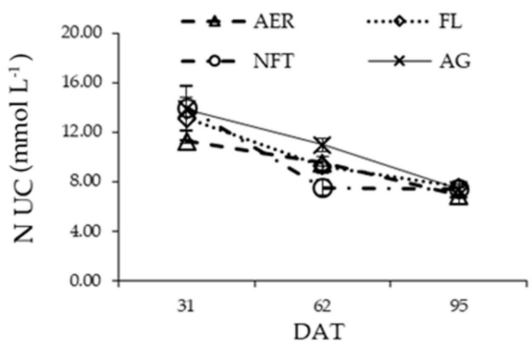

(b)

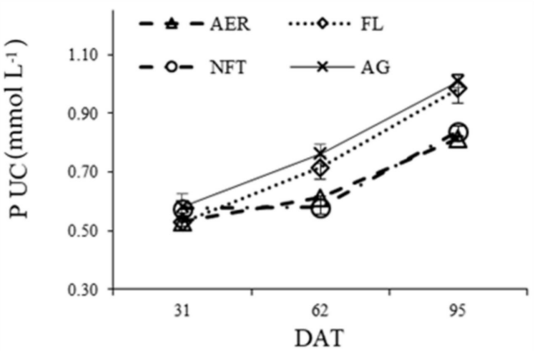

(d)

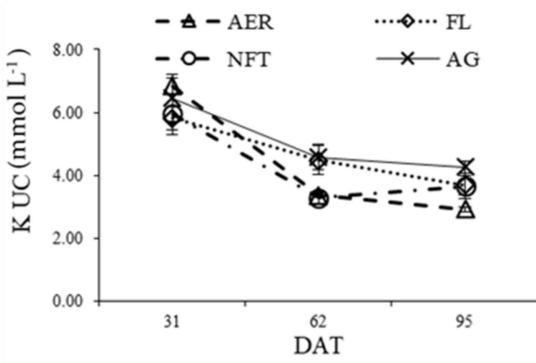

$(\mathrm{f})$

Figure 7. Impact of the different CSCS on the concentrations in the plant dry mass (DM) and on the corresponding apparent uptake concentrations (UC), i.e., mmol of the element uptake per L of water uptake of N, P, and K. Vertical bars indicate \pm standard errors of means of twelve (12) samples per replicate.

The tissue $\mathrm{Mg}$ concentration presented slight fluctuations during the experiment (Figure 8c). At 31 DAT, there was a small increase in the tissue $\mathrm{Mg}$ concentration in AER and NFT plants, while in the rest of the CSCS a decrease was found, with the AG plants recording the lowest value $\left(1.73 \mathrm{mg} \mathrm{g}^{-1} \mathrm{DW}\right)$. The concentration of $\mathrm{Mg}$ in all plants decreased during the 2nd sampling and increased again at the end of the experiment with the exception of NFT plants, which showed a slight but steady decrease. NFT plants recorded the highest concentrations during the last two samplings. The UC of $\mathrm{Mg}$ showed a fluctuation pattern with the highest values recorded during the 1st and the 3rd sampling (0.27 $\mathrm{mmol} \mathrm{L}^{-1}$ and $0.29 \mathrm{mmol} \mathrm{L}^{-1}$, respectively) (Figure $8 \mathrm{~d}$ ). The lowest values were recorded during the 2 nd sampling (i.e., $62 \mathrm{DAT})$ near the time of bulbing $\left(0.16 \mathrm{mmol} \mathrm{L}^{-1}\right)$.

The tissue $S$ concentration and the UC of $S$ showed a slightly increasing tendency during the experiment (Figure 8e). At 31 DAT, the $S$ tissue concentration of the FL and the AG plants was significantly higher than in the rest of the treatments. There were no further effects recorded during the rest of the experiment. The UC of S was significantly higher in the AG system during the last cropping period (maturation), while it was not influenced by the CSCS at earlier cropping stages (Figure $8 \mathrm{f}$ ). 


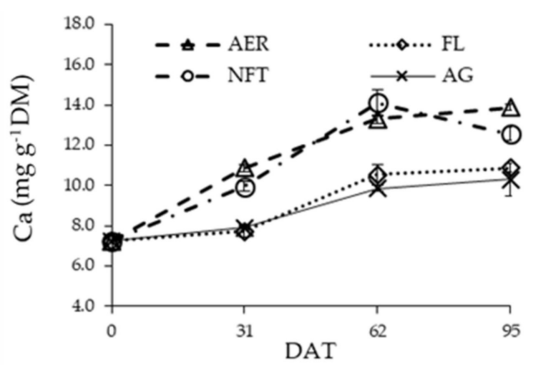

(a)

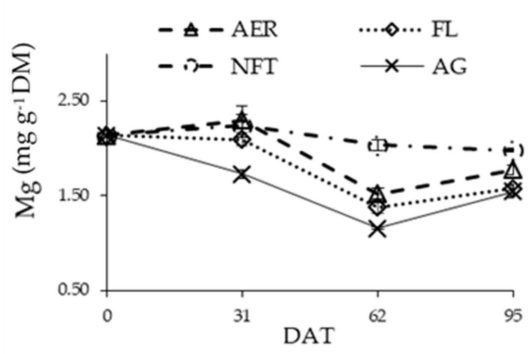

(c)

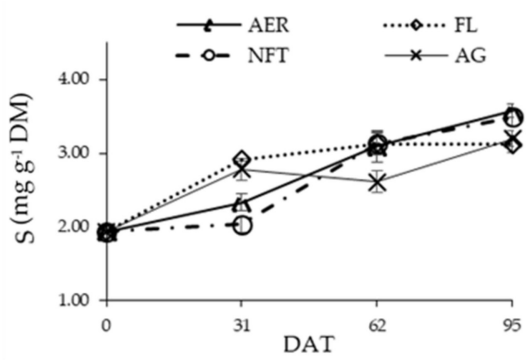

(e)

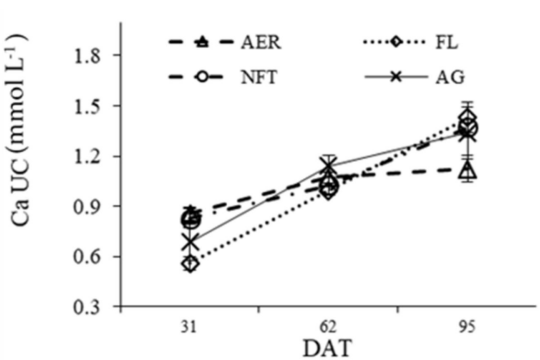

(b)

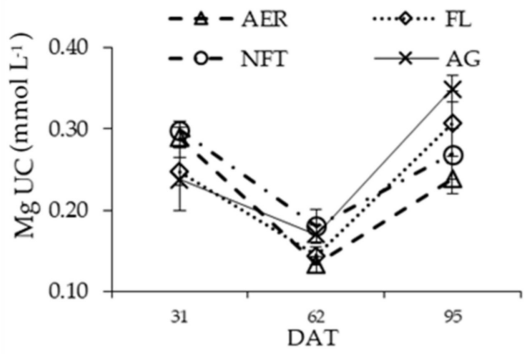

(d)

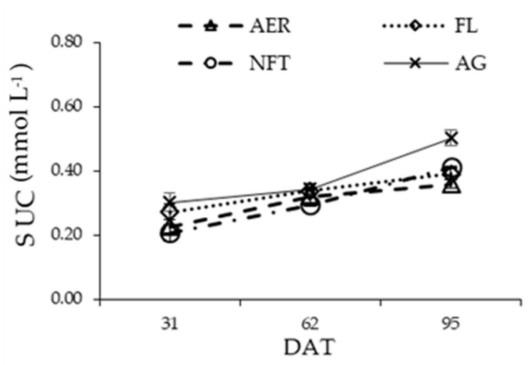

(f)

Figure 8. Impact of the different CSCS on the concentrations in the plant dry mass (DM) and on the corresponding apparent uptake concentrations (UC), i.e., mmol of the element uptake per L of water uptake of $\mathrm{Ca}, \mathrm{Mg}$, and $\mathrm{S}$. Vertical bars indicate \pm standard errors of means of twelve (12) samples per replicate.

\section{Discussion}

Plant growth of Nerokremmydo of Zakynthos follows the typical growth of an onion plant as described by other researchers [53,54]. Plants of this landrace grown in AG and FL systems appeared to adjust faster to their environment during the first main growth stage (up to 31 DAT). This was reflected by the plant height and LLMD superiority of FL and AG plants (Figure 3b,c). The longer pseudostem of NFT (Figure 3d), resulted in less photosynthetic area, as the larger parts of the leaves are "scaled" next to each other [55]. FL plants developed a rather long pseudostem but this was accompanied by larger leaves. The neck diameter is of primary importance; transverse growth and thickening of the upper part of the sheaths reflect commensurate changes in the transpiration stream. A smaller neck diameter, which was observed in NFT-grown plants, restricts the osmotically active solutes in the outer cells of the sheaths, thus pumping less water and nutrients, which leads to reduced cell swelling [41]. The differences in the shape index and sphericity of early bulbs observed in FL and AG (Figure 6e,f) can be attributed to the higher rate of swelling compared to the rate of elongation of the leaf base, which favored growing in diameter rather than in height. The reasons for the superiority of these two systems in terms of shape index and sphericity are somewhat different. The greater height and shape index in AG plants can be attributed to faster cell division while in FL plants it appears to be a 
result of water accumulation, as indicated by the larger plant FW and the lower \%DM in the FL treatment (Table 4).

Bulbing, i.e., BR $>2$ (Figure 4a), was first recorded when the day length exceeded $14.5 \mathrm{~h}$ (Figure 4f). According to US standards, [56] the day length needed to bulb classifies onions into short, intermediate, and long-day types when daytime is greater than or equal to $11-12,13-14$, and greater than $14 \mathrm{~h}$, respectively. Brewster [41] in a broader approach, incorporated the $14 \mathrm{~h}$ limit within the intermediate category, referring to long-day type when bulbing occurs at $>16 \mathrm{~h}$ of day light. Taking into account that the ranges serve a rough approach to consider the suitability of a variety for cultivation in a specific climatic zone and season, Nerokremmydo of Zakynthos is considered an intermediate bulb onion.

NFT plants started bulbing earlier (Figure 4a), followed by the AER plants $(B R=1.96)$ which started bulbing one week earlier than in the rest of CSCS (59 DAT); this reflects the definition of BR itself. At $59 \mathrm{DAT}$, and $\mathrm{AER}_{\mathrm{BR}}$ and $\mathrm{NFT}_{\mathrm{BR}}$ approaching or exceeding 2, respectively, there was no significant difference of bulb diameter among the plants of the compared systems. However, the smaller denominator (neck diameter) of NFT and AER (Figure 4e) lead to recording of earlier bulbing. Considering the size of the compared CSCS, and the purpose of the experiment, the choice of monitoring the bulbing rate instead of the "leaf ratio" [41] was the only feasible option. The reasons for the smaller neck diameter should be investigated in the plant root adjustment to the systems architecture and the dominant conditions in the root zone. The NFT system provides little room for root growth, with consequent problems in the uniformity of the NS applied, oxygenation, and temperature [57-59]. It seems that the slight flow obstruction of NS by the growing root may have resulted in a partial impedance of NS supply and a daily partial lack of oxygen $[30,60]$. Air average temperature after 61 DAT ranged above $25.5{ }^{\circ} \mathrm{C}$ (Table 3) and the average duration of such temperatures from bulbing onwards was $>12 \mathrm{~h} \mathrm{day}^{-1}$ (data not shown). Temperatures exceeding $25.5^{\circ} \mathrm{C}$ are quite high, leading to onion yield reduction [61]. Additionally, average root ambient temperature followed air temperature, while the mean maximum temperatures exceeded $25.5{ }^{\circ} \mathrm{C}$ during the time from 16 to 30 DAT (Figure 2). Based on the maximum and average temperature values, it is concluded that high temperatures did not occur during the whole day (Figure 2), but for systems with low buffer temperature range, such as NFT and secondly AER, these extremes seem to have affected the root growth [62].

According to plant FW, \% DM in plant tissues (Table 4), and visual observations (Figure 5), AER favored root growth without a following increase of shoot size and mass; this is confirmed by research results reported by other investigators [63]. The onion has a root system that grows in concentric circles [64], with the older roots confined towards the bottom center of the disk. According to Bosch Serra et. al., [65], the maximum length of the root occurs about 15 days before bulbing, while the appearance of new roots is limited during the growth of the bulb. At $62 \mathrm{DAT}$, it was visually confirmed that the plants had entered the bulbing stage with roots of different ages and density (Figure 5). AG plants exhibited a typical root system, with few older roots towards the bottom center and some thicker roots which were probably a direct result of the plant response to nutrient supply [66]. In AER and NFT plants, the new roots (white) were already at full length concentrated at the bottom end and entangled with the older roots. Building on the findings of Qiansheng et al. [63] concerning AER drawbacks that are associated with the position of the nebulizers applying the NS, and the time intervals between irrigations, it seems that during root renewal, the older roots of AER and NFT plants may partly impede NS supply with commensurate problems as discussed above. FL plants developed some new white roots, thicker and less branched than the older ones (light brown), a typical characteristic of new onion roots [64]. In FL, the plants adapted better, due to the ample nutrient disposal and the available root space [28]. Any new roots observed after bulbing and until maturation, are probably genotypically and nutritionally controlled; further differences can be explained based on the provision of nutrients and the individual 
conditions in the compared systems. Since no new leaves were recorded, the role of such new roots was presumably to accumulate assimilates.

The largest increase in the rate of fresh biomass production occurred during the period before bulbing (Table 4). The increase ranged between 48 and $70 \%$ for NFT and AG respectively, reflecting the increase in NS consumption (Table 6) and plant biomass accumulation (Table 4). The importance of sufficient water availability before and during bulbing in onion plants has been confirmed experimentally [58,67]. For reasons already discussed, NFT plants had reduced plant biomass and yield performance, suggesting a less efficient transpiration stream, which was confirmed by reduced CNS and commensurate hysteresis in WUE. In contrast, the WUE in AG was highest due to increased plant biomass production. The larger neck in FL and AG plants, in combination with no significant differences in leaf area, presumably point to a thicker leaf morphology at the base of the pseudostem, allowing for better water and nutrient movement. Records of the maximum values of plant height, leaves number, and neck diameter for all the compared CSCS (Figure 3f) coincide with the bulbing date and are in agreement with Brewster [41].

At harvest, based on the number of leaves per plant, the plant height, and the neck diameter, AG plants exhibited a later maturation tendency; nevertheless, $70 \%$ of tops fell over due to soft necks. According to Kamenetsky and Rabinowitch [68] the number of leaves has a decisive role in yield success. It is probable that continuing with irrigation in AG would lead to a later harvest but this requires further investigation. In addition to the cumulative effects of water consumption and neck size during the critical period of bulbing, at harvest, AG and FL plants prevailed. It has been reported that plant growth parameters, such as plant height and bulb diameter, correlate positively with bulb yield [47,69], LLMD, pseudostem length, neck diameter (Figure 3c,d,e), bulb diameter, height, surface area, and volume (Figure $6 \mathrm{a}, \mathrm{b}, \mathrm{c}, \mathrm{d}$ ). Such correlations are consistent with the observed FL and AG superiority to the rest of the compared systems in terms of FW (Table 4) and yield (Table 5).

Moisture concentration in fresh onions is higher than in onions dried for long storage [70]. Additionally, large bulb onions have a higher moisture percentage [71]. Here, the high moisture percentage $(>91 \%)$ confirm that Nerokremmydo should be treated as a fresh mild onion with reduced shelf life [70], implying a relatively short period of availability in local markets. According to our findings (Table 5), bulb \%DM averaged 8.17\%, which is similar to that of other sweet onions [72,73]. The development of plant \% DM (Table 4) shows that its greatest increase occurred after bulbing and up to harvest, in agreement with relevant findings of other researchers [74,75]. The differences in \% DM between the CSCS were due to dilution or condensation effects for FL and NFT plants, respectively. Schmautz et. al., [59] have presented similar ranking results (AG > FL \%DM) with cherry tomato. At harvest, plant \%DM differences followed the sequence NFT $\geq \mathrm{AG} \geq \mathrm{AER}>\mathrm{FL}$ which is not reflective of the bulb measurements; probably due to the inclusion of dry leaves in the calculation of plant \%DM. The percentage of DM in bulbs produced in NFT did not differ from that measured in AG plants, probably due to lower TCNS in the former (Table 6). It has been reported that impending water absorption positively affected the dry weight in AER in comparison to AG and soil trial of lemon balm [76]. Temperature differences in the root rhizosphere during bulbing and afterwards, may have also contributed to differences in the DM percentage between bulbs in different treatments.

The yield obtained by cultivating in CSCS surpassed the range of $3.25-3.75 \mathrm{~kg} \mathrm{~m}^{-2}$ reported by local farmers (personal communication) and the national onion yield, i.e., $3.53 \mathrm{~kg} \mathrm{~m}^{-2}$ [77], exceeding them by 38 and $142 \%$ for NFT and FL, respectively (Table 5). It is known that yield depends on plant density, variety, and conditions during cultivation. According to Siracusa et al., [3], Cipolla di Giarratana, a local onion landrace (Syracuse, Sicily), morphologically similar to Nerokremmydo of Zakynthos, yielded $15.1 \mathrm{~kg} \mathrm{~m}^{-2}$. Considering that the plant density applied in Sicily is $\sim 2.5$ times greater than local practice in Zakynthos, and prevailing conditions, the yield difference is reasonable. Trials in Kentucky (U.S.A.) [56] on long day mild onions, Walla Walla and Ailsa Craig, yielded $3.38 \mathrm{~kg} \mathrm{~m}^{-2}$. The Vidalia onion (GA, USA), a trade name for several short-day mild onion 
varieties of declared specifications, depending on the year's conditions, reached $7.0 \mathrm{~kg} \mathrm{~m}^{-2}$. Jaune des Cévennes and Paille des Vertus (France) yielded 3.3 and $1.3 \mathrm{~kg} \mathrm{~m}^{-2}$, respectively [73]. FL and AG outperformed the other two CSCS in yield. Nerokremmydo of Zakynthos adapted best in two completely different CSCS, supporting the view that system management is of paramount importance for crop success [28]. Water content in FL was the most marked component without compromising the quality as described by non-significant SS (Table 5). The SS averaged 8.22 brix; the results surpassed or lagged behind the mildness of Cipolla di Giarratana and Jaune des Cévennes (6.73 and 11.9 respectively) [3,73], and exceeded the majority of the white and yellow varieties of mild onion in the U.S.A. [72,78,79].

According to Brewster [41], bulb onions usually have an increased harvest index (HI), with $80 \%$ of the shoot being concentrated in the bulb. HI values of Nerokremmydo averaged 0.703 (Table 5). It is known that plants with higher water consumption have a lower HI [80]. Similar onion HI values were obtained by Gonçalves et al., [75] and Kassa [81], (0.73 and 0.71 , respectively), while in standard cultivars of bulb onions, higher (0.85) [82], or lower values (0.23-0.48) [83] were found. Differences in CSCS may be explained by the combination of different plant FW, size of bulbs, plant size of AG and FL plants, and commensurate bulb dry weight distribution, as a result of better adaptation to the system. According to Schwarz [84], the HI is related to the root:shoot ratio, nutrition, salinity, and climatic conditions, that can induce stress effects, i.e., temperature, light, and radiation.

Bulb onions need curing to restrict humidity losses and to avoid the entrance of pathogens, thereby extending their shelf-life $[85,86]$. Even in varieties such as Nerokremmydo of Zakynthos (Bermuda type) curing is needed [87]. According to our findings (Table 5), \% plant moisture reduction (as described by the weight loss of the bulbs) before and after curing, averaged $24.5 \%$, similar to other mild onions [86], for the period traditionally applied for curing. The average \% of non-marketable onions (NMB) was $6.96 \%$, similar to the results of other trials [72,88]. The majority of the NMB of NFT bulbs were under the minimum market limit of $70 \mathrm{~mm}$. Of note is the non-appearance of NMB onions in the AG system.

In the present study, the macronutrients in plant tissues and the uptake concentrations studied were influenced by the CSCS compared and by the plant growth stage. The two, physiologically independent, mechanisms, namely nutrient uptake and water consumption, are determinatively controlled by sunlight, linearly and curvilinearly, respectively [89]. The increasing solar radiation over time, led to the downward trend of $\mathrm{N}$ and $\mathrm{K} \mathrm{UC}$ up to harvest (Figure $7 \mathrm{~b}, \mathrm{f}$ ) and Mg UC up to bulbing (Figure 8d) [90]. The downward trend of $\mathrm{N}$ concentration in plant tissues is expected as the plant matures [91]. Furthermore, the increased need for nutrients in the early stages of plant growth, which is not accompanied by adequate water absorption due to the size of the root and the leaves, increases uptake concentrations [33,34]. As leaf area increases with time, the demand for nutrients increases. The highest water consumption occurred during the bulbing stage, or shortly thereafter, as has been found by other researchers $[38,67]$. tissue potassium concentrations exceeded those of all other nutrients within each sampling, throughout the trial. The values and the downward trend of the K concentration agree with the results of Okada et al. [92] in onions grown under controlled conditions (plant factory). According to these authors, the gradual decrease in the tissue concentration of $\mathrm{K}$ is due to the increased absorption of water (Table 5), which is required for the swelling of the cells of the thickening sheaths that form the bulb. From the beginning to the end of the trial, $\mathrm{P}, \mathrm{Ca}$, and S UC showed a slight upward trend, indicating that the demand for $\mathrm{P}, \mathrm{Ca}$, and $\mathrm{S}$ during bulb maturation outweighs the corresponding water demand (Figures $7 \mathrm{~d}$ and $8 \mathrm{~b}, \mathrm{f}$ ). Phosphorus exhibited a similar trend in a study concerning the uptake concentrations of sweet pepper [34]. Furthermore, the increasing trend of $\mathrm{P}$ absorption in onions has been confirmed by Antoniadis et. al., [93]. Other studies $[94,95]$ have highlighted the increase of enzymes for sucrose metabolism, where $\mathrm{P}$ is needed. The initial decrease of the $\mathrm{Mg} \mathrm{UC}$ before, and its increase after bulbing, may be due to a combination of causes. In addition to the already reported effects of increasing solar radiation over time, and sucrose metabolism, its competition with K (62 DAT) 
may also have partially affected the reduction in $\mathrm{Mg}[96,97]$. Generally, the C and UC of macronutrients exhibited notable uniformity in changes over time between the compared CSCS.

At bulbing (61 DAT), the difference in nutrient concentration between AG and the water-culture CSCS, was probably due to luxury consumption in the latter. The mean UC of $\mathrm{N}$ dropped by $30 \%$ of its initial value (31 DAT). The reduced UC of N by NFT plants is explained by the reduced absorption of nutrients and water (Table 5) due to inadequacies in root efficiency, as discussed above. The choice of the $\mathrm{NH}_{4}{ }^{+}: \mathrm{NO}_{3}{ }^{-}$ratio regulates cation absorption, as stated by Abbès et al. [98]. The FL and AG plants showed increased K and P UC values during bulbing. The much larger increase of dry weight, along with the analogous water consumption, support this. Tissue K concentrations ranging around $4.8 \%$ measured in AG fall within the sufficiency range suggested by the literature of 3.5-5.5\% for sweet onions during the middle of the growing season [72]. Hence any extra uptake of $\mathrm{K}$, while antagonistically interfering with $\mathrm{Ca}$ and $\mathrm{Mg}$ uptake, could lead to an increase in production costs, without a significant contribution to final production [72],

From maturing and up to harvest, the tested CSCS did not affect the UC of N, Ca, and $\mathrm{Mg}$. At this stage, there is an accumulation of nutrients in the bulb, an evolutionary feature of the bulbs aiming to cope with the adverse conditions of temperature and lack of humidity in summer [41]. The tissue N, P, K, and Ca levels were significantly higher in AER plants compared to those measured in the other three CSCS, due to higher availability of new roots in this system (visual assessment) which continued to appear as the plant adapted to the increased temperatures inside the root growth chamber (Figure 2). The plants in the FL system were also developing new roots, although in terms of tissue nutrient concentrations, they showed an intermediate behavior between AER and NFT, similar to that of AG plants. The $P$ concentration increased to meet the increased metabolic processes of stored bulbs. The higher values of P UC of FL and AG plants, reflect higher growth rates of the bulbs, a process that requires energy consumption, showing similar differences with those recorded in the bulbing phase. The small differences of K UC between the water-culture systems could be explained by the individual needs of $\mathrm{K}$ for controlling the open and closure of stomata to balance the varying transpirational stream, especially during the high photosynthetic rates of the day [99]. According to Okada et. al., [92], after commencement of bulbing, a further absorption of $\mathrm{K}$ is noticed, in addition to the bulb sinking from leaves. An adequate supply of $\mathrm{K}$ has been shown to improve vegetable quality compared to that obtained under K shortage conditions [100,101], especially in onions, and improves shelf life [85]. The UC of S in AG recorded the largest increase between the compared CSCS during the maturation period (Figure 8f). This increase indicates the production of structural proteins, which need S-containing amino acids to be biosynthesized [102].

\section{Conclusions}

It appears that Nerokremmydo of Zakynthos, a Greek intermediate day-length big-bulb variety of mild onion, adapts well in CSCS which eliminate soil problems and nutrient pollution of groundwater, and enhance yield. Water and nutrient availability during bulbing are crucial factors for yield performance. Under the conditions prevailing in the current experiment, FL and AG outperformed the other two systems, followed by AER, while NFT was the least efficient in terms of plant biomass, bulb size, total yield, and WUE. Cultivation in AER and NFT resulted in the highest tissue macronutrient concentrations, probably due to root prevalence, and condensation effects, respectively. UC followed a similar evolution over time in the different CSCS and may be used to establish typical nutrient solution formulations for mild onion cultivation in CSCS. Control of NS temperature and adjustments of CSCS structural components in each system may mitigate the recorded differences. 
Author Contributions: Conceptualization, C.M., A.K. and D.S.; Data curation, C.M., A.K. and D.S.; Formal analysis C.M., A.K., G.N. and D.S.; Funding acquisition, A.K., G.N. and D.S.; Investigation, C.M., A.K., G.N. and D.S.; Methodology, C.M., A.K., G.N. and D.S.; Project administration, A.K. and D.S.; Resources, C.M., A.K. and D.S.; Software, C.M., A.K., G.N. and D.S.; Supervision A.K. and D.S.; Validation, C.M., A.K., G.N. and D.S.; Visualization, C.M., A.K., G.N. and D.S.; Writing-original draft, C.M., A.K., G.N. and D.S.; Writing—review \& editing, C.M., A.K., G.N. and D.S. All authors have read and agreed to the published version of the manuscript.

Funding: This research received no external funding.

Informed Consent Statement: Not applicable.

Data Availability Statement: The raw data supporting the conclusions of this article will be made available by the authors, without undue reservation.

Conflicts of Interest: The authors declare no conflict of interest.

\section{References}

1. FAOSTAT Database. Available online: http://www.fao.org/faostat/en/\#data/QC (accessed on 2 March 2021).

2. Dritsas, P. Kremmydi Thespion. Available online: https://www.ecpgr.cgiar.org/in-situ-landraces-best-practice-evidence-baseddatabase/landrace?landraceUid=13272 (accessed on 21 March 2021).

3. Siracusa, L.; Avola, G.; Patanè, C.; Riggi, E.; Ruberto, G. Re-evaluation of traditional mediterranean foods. the local landraces of "cipolla di giarratana" (Allium Cepa L.) and long-storage tomato (Lycopersicon Esculentum 1.): Quality traits and polyphenol content. J. Sci. Food Agric. 2013, 93, 3512-3519. [CrossRef]

4. Díaz-Pérez, J.C.; Bautista, J.; Gunawan, G.; Bateman, A.; Riner, C.M. Sweet onion (Allium Cepa L.) as influenced by organic fertilization rate: 1. plant growth, and leaf and bulb mineral composition. HortScience 2018, 53, 451-458. [CrossRef]

5. USDA. United States Standards for Grades of Bermuda-Granex-Grano Type Onions; USDA: Washington, DC, USA, $2014 ;$ p. 11.

6. Cherry, K. Allium Root Rot. Available online: https://projects.ncsu.edu/cals/course/pp728/sclerotium_cepivorum/Sclerotium_ cepivorum.html (accessed on 6 March 2021).

7. Frye, J. Pink Root of Onion. Available online: https://projects.ncsu.edu/cals/course/pp728/Phoma/Phoma_terrestris.html (accessed on 6 March 2021).

8. Gruda, N. Do soilless culture systems have an influence on product quality of vegetables? J. Appl. Bot. Food Qual. 2009, 82, 141-147. [CrossRef]

9. Savvas, D.; Gianquinto, G.; Tuzel, Y.; Gruda, N. Soilless culture. In Good Agricultural Practices for Greenhouse Vegetable CropsPrinciples for Mediterranean Climate Areas; Baudoin, W., Nono-Womdim, R., Lutaladio, N., Hodder, A., Castilla, N., Leonardi, C., De Pascale, S., Eds.; FAO: Rome, Italy, 2013; pp. 303-354, ISBN 978-92-5-107649-1.

10. Monteiro, J.; Teiel, M.; Baeza, E.; Lopez, J.C.; Karica, M. Greenhouse design and covering materials. In Good Agricultural Practices for Greenhouse Vegetable Crops_Principles for Mediterranean Climate Areas; FAO: Rome, Italy, 2013; pp. 35-62, ISBN 978-92-5-107649-1.

11. Son, J.E.; Kim, H.J.; Ahn, T.I. Hydroponic Systems. In Plant Factory: An Indoor Vertical Farming System for Efficient Quality Food Production; Kozai, T., Niu, G., Tagaki, M., Eds.; Academic Press: Cambridge, MA, USA, 2016; pp. 213-221, ISBN 978-0-12-801775-3.

12. Lommen, W.J.M. The canon of potato science: 27. Hydroponics. Potato Res. 2007, 50, 315-318. [CrossRef]

13. Savvas, D.; Gruda, N. Application of soilless culture technologies in the modern greenhouse industry-A review. Eur. J. Hortic. Sci. 2018, 83, 280-293. [CrossRef]

14. Alshrouf, A. Hydroponics, Aeroponic and Aquaponic as Compared with Conventional Farming. Am. Sci. Res. J. Eng. Technol. Sci. 2017, 27, 247-255.

15. Lakhiar, I.A.; Gao, J.; Syed, T.N.; Chandio, F.A.; Buttar, N.A. Modern plant cultivation technologies in agriculture under controlled environment: A review on aeroponics. J. Plant Interact. 2018, 13, 338-352. [CrossRef]

16. Tunio, M.H.; Gao, J.; Shaikh, S.A.; Lakhiar, I.A.; Qureshi, W.A.; Solangi, K.A.; Chandio, F.A. Potato production in aeroponics: An emerging food growing system in sustainable agriculture for food security. Chil. J. Agric. Res. 2020, 80, 118-132. [CrossRef]

17. Salachas, G.; Savvas, D.; Argyropoulou, K.; Tarantillis, P.A.; Kapotis, G. Yield and nutritional quality of aeroponically cultivated basil as affected by the available root-zone volume. Emirates J. Food Agric. 2015, 27, 911-918. [CrossRef]

18. Wong, C.E.; Teo, Z.W.N.; Shen, L.; Yu, H. Seeing the lights for leafy greens in indoor vertical farming. Trends Food Sci. Technol. 2020, 106, 48-63. [CrossRef]

19. Tüzel, Y.; Gül, A.; Tüzel, I.H.; Öztekin, G.B. Different Soilless Culture Systems and Their Management. J. Agric. Food Environ. Sci. 2019, 73, 7-12.

20. Walters, K.J.; Currey, C.J. Hydroponic greenhouse basil production: Comparing systems and cultivars. Horttechnology 2015, 25, 645-650. [CrossRef]

21. Kyriacou, M.C.; De Pascale, S.; Kyratzis, A.; Rouphael, Y. Microgreens as a Component of Space Life Support Systems: A Cornucopia of Functional Food. Front. Plant Sci. 2017, 8, 1-4. [CrossRef]

22. Domingues, D.S.; Takahashi, H.W.; Camara, C.A.P.; Nixdorf, S.L. Automated system developed to control pH and concentration of nutrient solution evaluated in hydroponic lettuce production. Comput. Electron. Agric. 2012, 84, 53-61. [CrossRef] 
23. Hochmuth, R.C.; Cantliffe, D. Greenhouse Cucumber Production-Florida Greenhouse Vegetable Production Handbook; University of Florida: Gainesville, FL, USA, 2018; Volume 3.

24. Burrage, S.W. The nutrient film technique (NFT) for crop production in the mediterranean region. Acta Hortic. 1999, 491, 301-305. [CrossRef]

25. Alsmairat, N.G.; Al-Ajlouni, M.G.; Ayad, J.Y.; Othman, Y.A.; Hilaire, R.S. Composition of soilless substrates affect the physiology and fruit quality of two strawberry (Fragaria $\times$ ananassa Duch.) cultivars. J. Plant Nutr. 2018, 41, 2356-2364. [CrossRef]

26. Bar-Tal, A.; Saha, U.K.; Raviv, M.; Tuller, M. Inorganic and synthetic organic components of soilless culture and potting mixtures. In Soilless Culture: Theory and Practice Theory and Practice; Elsevier: Amsterdam, The Netherlands, 2019; pp. 259-301, ISBN 9780444636966.

27. Benton, J.J.J. Hydroponics A Practical Guide for the Soilless Grower, 2nd ed.; CRC Press Taylor \& Francis Group: Boca Raton, FL, USA, 2004.

28. Rodríguez-Ortega, W.M.; Martínez, V.; Nieves, M.; Simón, I.; Lidón, V.; Fernandez-Zapata, J.C.; Martinez-Nicolas, J.J.; Cámara-Zapata, J.M.; García-Sánchez, F. Agricultural and Physiological Responses of Tomato Plants Grown in Different Soilless Culture Systems with Saline Water under Greenhouse Conditions. Sci. Rep. 2019, 9, 1-13. [CrossRef]

29. Tabatabaei, S.J. Effects of cultivation systems on the growth, and essential oil content and composition of valerian. J. Herbs Spices Med. Plants 2008, 14, 54-67. [CrossRef]

30. Blok, C.; Jackson, B.E.; Guo, X.; De Visser, P.H.B.; Marcelis, L.F.M. Maximum plant uptakes for water, nutrients, and oxygen are not always met by irrigation rate and distribution in water-based cultivation systems. Front. Plant Sci. 2017, 8, 1-15. [CrossRef]

31. Eldridge, B.M.; Manzoni, L.R.; Graham, C.A.; Rodgers, B.; Farmer, J.R.; Dodd, A.N. Getting to the roots of aeroponic indoor farming. New Phytol. 2020, 228, 1183-1192. [CrossRef]

32. Tzerakis, C.; Savvas, D.; Sigrimis, N. Responses of cucumber grown in recirculating nutrient solution to gradual Mn and Zn accumulation in the root zone owing to excessive supply via the irrigation water. J. Plant Nutr. Soil Sci. 2012, 175, 125-134. [CrossRef]

33. Neocleous, D.; Savvas, D. Effect of different macronutrient cation ratios on macronutrient and water uptake by melon (Cucumis melo) grown in recirculating nutrient solution. J. Plant Nutr. Soil Sci. 2015, 178, 320-332. [CrossRef]

34. Ropokis, A.; Ntatsi, G.; Kittas, C.; Katsoulas, N.; Savvas, D. Impact of cultivar and grafting on nutrient and water uptake by sweet pepper (capsicum annuum 1.) grown hydroponically under mediterranean climatic conditions. Front. Plant Sci. 2018, 9, 1-12. [CrossRef] [PubMed]

35. Ropokis, A.; Ntatsi, G.; Rouphael, Y.; Kotsiras, A.; Kittas, C.; Katsoulas, N.; Savvas, D. Responses of sweet pepper (Capsicum annum L.) cultivated in a closed hydroponic system to variable calcium concentrations in the nutrient solution. J. Sci. Food Agric. 2021, 101, 4342-4349. [CrossRef] [PubMed]

36. Inal, A.; Tarakcioglu, C. Effects of nitrogen forms on growth, nitrate accumulation, membrane permeability, and nitrogen use efficiency of hydroponically grown bunch onion under boron deficiency and toxicity. J. Plant Nutr. 2001, 24, 1521-1534. [CrossRef]

37. Kane, C.D.; Jasoni, R.L.; Peffley, E.P.; Thompson, L.D.; Green, C.J.; Pare, P.; Tissue, D. Nutrient solution and solution pH influences on onion growth and mineral content. J. Plant Nutr. 2006, 29, 375-390. [CrossRef]

38. Gamiely, S.; Randle, W.M.; Mills, H.A.; Smittle, D.A.; Banna, G.I. Onion Plant Growth, Bulb Quality, and Water Uptake following Ammonium and Nitrate Nutrition. HortScience 1991, 26, 1061-1063. [CrossRef]

39. Güneş, A.; Inal, A.; Aktaş, M. Reducing nitrate content of NFT grown winter onion plants (Allium Cepa L.) by partial replacement of NO3 with amino acid in nutrient solution. Sci. Hortic. 1996, 65, 203-208. [CrossRef]

40. De Kreij, C.; Voogt, W.; Baas, R. Nutrient Solutions and Water Quality for Soilless Cultures; Applied Plant Research, Division Glasshouse: London, UK, 1999.

41. Brewster, J.L. (Ed.) Onions and Other Vegetable Alliums, 2nd ed; Cab International: Wellesbourne, UK, 2008; ISBN 978-1-84593-399-9.

42. Amer Essa, A.H.; Gamea, G.R. Physical and Mechanical Properties of Bulb Onions. Misr J. Agric. Eng. 2003, 20, 661-676. [CrossRef]

43. Bosekeng, G. Response of Onion (Allium Cepa L.) to Swing Date and Plant Population. Ph.D. Thesis, University of the Free State Bloemfontein, Bloemfontein, South Africa, 2012.

44. Mohsenin, N.N. Physical Properties of Plant and Animal Materials: Structure, Physical Characteristics and Mechanical Properties, 2nd ed.Gordon and Breach Science Publishers: London, UK, 1986.

45. Stroshine, R. Physical Properties of Agricultural Materials and Food Products; R. Stroshine: West Lafayette, IN, USA, 2004.

46. Nabi, G.; Rab, A.; Sajid, M.; Ullah, F.; Abbas, S.J.; Ali, I. Influence of curing methods and storage conditions on the post-harvest quality of onion bulbs. Pakistan J. Bot. 2013, 45, 455-460.

47. Abdissa, Y.; Tekalign, T.; Pant, L.M. Growth, bulb yield and quality of onion (Allium Cepa L.) as influenced by nitrogen and phosphorus fertilization on vertisol I. growth attributes, biomass production and bulb yield. African J. Agric. Res. 2011, 6, 3252-3258. [CrossRef]

48. Rouphael, Y.; Colla, G.; Cardarelli, M.; Fanasca, S.; Salerno, A.; Rivera, C.M.; Rea, E.; Karam, F. Water use efficiency of greenhouse summer squash in relation to the method of culture: Soil vs. Soilless. Acta Hortic. 2005, 697, 81-86. [CrossRef]

49. Horneck, D.; Miller, R. Determination of total nitrogen in plant tissue. In Methods for Plant Analysis—Tissue Tests—Let Plants Speak; Kalra, Y.P., Ed.; CRC Press Taylor \& Francis Group: Boca Ratoon, FL, USA, 1998; p. 291.

50. Murphy, J.; Riley, J.P. A modified single solution method for the determination of phosphate in natural waters. Anal. Chim. Acta 1962, 27, 31-36. [CrossRef] 
51. Tabatabai, M.A.; Bremner, J.M. A Simple Turbidimetric Method of Determining Total Sulfur in Plant Materials. Agron. J. 1970, 62, 805-806. [CrossRef]

52. Tzerakis, C.; Savvas, D.; Sigrimis, N.; Mavrogiannopoulos, G. Uptake of Mn and Zn by cucumber grown in closed hydroponic systems as influenced by the Mn and Zn concentrations in the supplied nutrient solution. HortScience 2013, 48, 373-379. [CrossRef]

53. Addai, I.K.; Anning, D.K. Response of onion (Allium Cepa L.) to bulb size at planting and NPK 15:15:15 fertilizer application rate in the Guinea savannah agroecology of Ghana. J. Agron. 2015, 14, 304-309. [CrossRef]

54. Backes, C.; Bôas, R.L.V.; De Godoy, L.J.G.; Vargas, P.F.; Santos, A.J.M. Determination of growth and nutrient accumulation in bella vista onion. Rev. Caatinga 2018, 31, 246-254. [CrossRef]

55. Nobel, P.S. Chapter 7-Temperature and Energy Budgets. In Physicochemical and Environmental Plant Physiology, 4th ed.; Academic Press: San Diego, CA, USA, 2009; pp. 318-363, ISBN 978-0-12-374143-1.

56. Coolong, T.; Williams, M.A. Overwintering potential of onion in Kentucky. Horttechnology 2014, 24, 590-596. [CrossRef]

57. Van Os, E.; Gieling, T.H.; Lieth, J.H. Technical equipment in soilless production systems. In Soilless Culture: Theory and Practice Theory and Practice; Raviv, M., Lieth, J., Eds.; Elsevier: Amsterdam, The Netherlands, 2008; pp. 157-207.

58. Pérez Ortolá, M.; Knox, J.W. Water Relations and Irrigation Requirements of Onion (Allium Cepa L.): A Review of Yield and Quality Impacts. Exp. Agric. 2015, 51, 210-231. [CrossRef]

59. Schmautz, Z.; Loeu, F.; Liebisch, F.; Graber, A.; Mathis, A.; Bulc, T.G.; Junge, R. Tomato productivity and quality in aquaponics: Comparison of three hydroponic methods. Water 2016, 8, 533. [CrossRef]

60. Suhl, J.; Oppedijk, B.; Baganz, D.; Kloas, W.; Duijn, B. Van Oxygen consumption in recirculating nutrient film technique in aquaponics. Sci. Hortic. 2019, 255, 281-291. [CrossRef]

61. Khokhar, K.M. Environmental and genotypic effects on bulb development in onion-A review. J. Hortic. Sci. Biotechnol. 2017, 92, 448-454. [CrossRef]

62. Papadopoulos, A.P.; Hao, X. Interactions between nutrition and environmental conditions in hydroponics. In Hydroponic Production of Vegetables and Ornamentals; Savvas, D., Passam, H.C., Eds.; Embryo Publications: Athens, Greece, 2002; pp. 413-445.

63. Qiansheng, L.; Xiaoqiang, L.; Tang, B.; Mengmeng, G. Growth responses and root characteristics of lettuce grown in Aeroponics, Hydroponics, and Substrate Culture. Horticulturae 2018, 4, 35. [CrossRef]

64. Rubatzky, V.; Yamaguchi, M. World Vegetables: Principles, Production, and Nutritive Values, 2nd ed.; Springer: Dordrecht, The Netherlands, 1997; ISBN 978-1-4615-6015-9.

65. Bosch Serra, A.D.; Torrens, M.B.; Olivé, F.D.; Melines Pagès, M.A. Root growth of three onion cultivars. Dev. Crop Sci. 1997, 25, 123-133. [CrossRef]

66. Forde, B.; Lorenzo, H. The nutritional control of root development. Plant Soil 2001, 232, 51-68. [CrossRef]

67. Kadayifci, A.; Tuylu, G.I.; Ucar, Y.; Cakmak, B. Crop water use of onion (Allium Cepa L.) in Turkey. Agric. Water Manag. 2005, 72, 59-68. [CrossRef]

68. Kamenetsky, R.; Rabinowitch, H.D. Physiology of Domesticated Alliums: Onions, Garlic, Leek, and Minor Crops, 2nd ed.; Elsevier: Amsterdam, The Netherlands, 2016; Volume 3, ISBN 9780123948083.

69. Nasreen, S.; Haque, M.M.; Hossain, M.A. Nitrogen and Sulphur Fertilization. Bangladesh J. Agric. Res. 2007, 32, 413-420. [CrossRef]

70. Shultz, S. Commodity of the quarter onions. J. Agric. Food Inf. 2010, 11, 8-15. [CrossRef]

71. Ko, S.S.; Chang, W.N.; Wang, J.F.; Cherng, S.J.; Shanmugasundaram, S. Storage variability among short-day onion cultivars under high temperature and high relative humidity, and its relationship with disease incidence and bulb characteristics. J. Am. Soc. Hortic. Sci. 2002, 127, 848-854. [CrossRef]

72. Díaz-Pérez, J.C.; Bautista, J.; Bateman, A.; Gunawati, G.; Riner, C. Sweet onion (Allium Cepa) plant growth and bulb yield and quality as affected by potassium and sulfur fertilization rates. HortScience 2016, 51, 1592-1595. [CrossRef]

73. Pérez, M.R.; Merkt, N.; Zikeli, S.; Zörb, C. Quality aspects in open-pollinated onion varieties from Western Europe. J. Appl. Bot. Food Qual. 2018, 91, 69-78. [CrossRef]

74. Thangasamy, A. Quantification of Dry-Matter Accumulation and Nutrient Uptake Pattern of Short Day Onion (Allium Cepa L.). Commun. Soil Sci. Plant Anal. 2016, 47, 246-254. [CrossRef]

75. Gonçalves, F.A.R.; De Aquino, P.M.; Duarte, L.O.; De Aquino, R.F.B.A.; Dos Reis, M.R.; De Aquino, L.A. Macronutrient extraction curves of the onion crop. Semin. Agrar. 2019, 40, 2497-2512. [CrossRef]

76. Son, Y.J.; Park, J.E.; Kim, J.; Yoo, G.; Nho, C.W. The changes in growth parameters, qualities, and chemical constituents of lemon balm (Melissa officinalis L.) cultivated in three different hydroponic systems. Ind. Crops Prod. 2021, 163, 113313. [CrossRef]

77. World's Leading Onion Producing Countries. Available online: https://www.atlasbig.com/en-ca/countries-by-onionproduction (accessed on 15 March 2021).

78. Vavrina, C.S.; Smittle, D.A. Evaluating Sweet Onion Cultivars for Sugar Concentrations and Pungency. HortScience 1993, 28, 804-806. [CrossRef]

79. Russo, V.M. Nutrient content and yield in relation to top breakover in onion developed from greenhouse-grown transplants. $J$. Sci. Food Agric. 2009, 89, 815-820. [CrossRef]

80. Cooper, J.; Scherer, H. Nitrogen Fixation. In Marschner's Mineral Nutrition of Higher Plants, 3rd ed.; Marschner, P., Ed.; Academic Press: San Diego, CA, USA, 2012; pp. 389-408. 
81. Kassa, A. Evaluation of Yield and Yield Components of Onion (Allium Cepa L.) Under Hatseva Condition, Israel AWOKE. Int. J. Agric. Innov. Res. 2018, 7, 50-58.

82. Kumara, B.R.; Mansur, C.P.; Chander, G.; Wani, S.P.; Alloli, T.B.; Jagadeesh, S.L.; Mesta, R.K.; Satish, D.; Meti, S.; Reddy, S.G. Effect of Potassium Levels, Sources and Time of Application on Storage Life of Onion (Allium Cepa L.). Int. J. Pure Appl. Biosci. 2018, 6, 540-549. [CrossRef]

83. Bettoni, M.M.; Mogor, Á.F.; Pauletti, V.; Goicoechea, N.; Aranjuelo, I.; Garmendia, I. Nutritional quality and yield of onion as affected by different application methods and doses of humic substances. J. Food Compos. Anal. 2016, 51, 37-44. [CrossRef]

84. Schwarz, M. Advanced Series in Agricultural Sciences 24 Soilless Culture Management; McNeal, B.L., Tardieu, F., Van Keulen, H., Van Vleck, D., Eds.; Springer: Berlin/Heidelberg, Germany, 1995; ISBN 978-3-642-79095-9.

85. Petropoulos, S.A.; Ntatsi, G.; Ferreira, I.C.F.R. Long-term storage of onion and the factors that affect its quality: A critical review. Food Rev. Int. 2017, 33, 62-83. [CrossRef]

86. Maw, B.W.; Mullinix, B.G. Moisture loss of sweet onions during curing. Postharvest Biol. Technol. 2005, 35, 223-227. [CrossRef]

87. Opara, L. Onion Post-Harvest Operations; FAO: Rome, Italy, 2003.

88. El-Desuki, M.; Mahmoud, A.R.; Hafiz, M.M. Response of Onion Plants to Minerals and Bio-fertilizers Application. Res. J. Agric. Biol. Sci. 2006, 2, 292-298.

89. Sonneveld, C. Composition of nutrient solutions. In Hydroponic Production of Vegetables and Ornamentals; Savvas, D., Passam, H., Eds.; Embryo Publications: Athens, Greece, 2002; pp. 179-210.

90. Sonneveld, C.; Voogt, W. Plant Nutrition of Greenhouse Crops; Springer: Berlin/Heidelberg, Germany, 2009; Volume 53, ISBN 978-85-781-107-96.

91. Barker, A.V.; Bryson, G.M. Nitrogen. In Handbook of Plant Nutrition; Barker, A., Pilbeam, D.J., Eds.; Taylor \& Francis Group, LLC: Boca Ratoon, FL, USA, 2007; pp. 22-50.

92. Okada, H.; Abedin, T.; Yamamoto, A.; Hayashi, T.; Hosokawa, M. Production of low-potassium onions based on mineral absorption patterns during growth and development. Sci. Hortic. 2020, 267, 109252. [CrossRef]

93. Antoniadis, V.; Petropoulos, S.A.; Golia, E.; Koliniati, R. Effect of phosphorus addition on onion plants grown in 13 soils of varying degree of weathering. J. Plant Nutr. 2017, 40, 2054-2062. [CrossRef]

94. Engels, C.; Kirkby, E.; White, P.J. Mineral Nutrition, Yield and Source-Sink Relationships. In Marschner's Mineral Nutrition of Higher Plants; Marschner, P., Ed.; Elsevier: Amsterdam, The Netherlands, 2012; pp. 89-133.

95. Zhang, C.; Zhang, H.; Zhan, Z.; Liu, B.; Chen, Z.; Liang, Y. Transcriptome analysis of sucrose metabolism during bulb swelling and development in onion (Allium Cepa L.). Front. Plant Sci. 2016, 7, 1-11. [CrossRef] [PubMed]

96. Madakadze, R.M.; Kwaramba, J. Effect of Preharvest Factors on the Quality of Vegetables Produced in the Tropics-Vegetables: Growing Environment and the Quality of Produce. In Production Practices and Quality Assessment of Food Crops Volume 1 Preharvest Practice; Dri, R., Jain, S.M., Eds.; Kluwer Academic Publishers: Dordrecht, The Netherlands, 2004; pp. 1-36, ISBN 1-4020-2533-5.

97. Hawkesford, M.; Horst, W.; Kichey, T.; Lambers, H.; Schjoerring, J.; Møller, S.I.; Philip, W. Functions of Macronutrients. In Marschner's Mineral Nutrition of Higher Plants; Marschner, P., Ed.; Elsevier: Amsterdam, The Netherlands, 2012; pp. 135-189.

98. Abbès, C.; Parent, L.E.; Karam, A.; Isfan, D. Effect of NH4+:NO3- ratios on growth and nitrogen uptake by onions. Plant Soil 1995, 171, 289-296. [CrossRef]

99. Khokhar, K.M. Mineral nutrient management for onion bulb crops-A review. J. Hortic. Sci. Biotechnol. 2019, 94, 703-717. [CrossRef]

100. Savvas, D.; Ntatsi, G.; Passam, H.C. The European Journal of Plant Science and Biotechnology Plant Nutrition and Physiological Disorders in Greenhouse Grown Tomato, Pepper and Eggplant. Eur. J. Plant Sci. Biotechnol. 2008, 2, 45-61.

101. Asao, T. (Ed.) Hydroponics—A Standard Methodology for Plant Biological Researches; InTech: London, UK, 2012; ISBN 9789535103868.

102. Boyhan, G. Sulfur, its role in onion production and related Alliums. In Sulfur: A Missing Link between Soils, Crops and Nutrition; Jez, J., Ed.; American Society of Agronomy; Crop Science Society of America; Soil Science Society of America: Madison, WI, USA, 2008; pp. 183-196. 